Article

\title{
The Strengths and Weaknesses of Pacific Islands Plastic Pollution Policy Frameworks
}

\author{
Trisia A. Farrelly ${ }^{1, * \mathbb{D}}$, Stephanie B. Borrelle ${ }^{2} \mathbb{D}$ and Sascha Fuller ${ }^{3} \mathbb{D}$ \\ 1 School of People, Environment and Planning, Massey University, Palmerston North 4442, New Zealand \\ 2 BirdLife International, Cambridge CB2 3QZ, UK; stephanie.borrelle@birdlife.org \\ Newcastle Institute for Energy and Resources, University of Newcastle, Callaghan, NSW 2308, Australia; \\ sascha.fuller@newcastle.edu.au \\ * Correspondence: T.Farrelly@massey.ac.nz; Tel.: +64-6-356-9099
}

check for

updates

Citation: Farrelly, T.A.; Borrelle, S.B.; Fuller, S. The Strengths and Weaknesses of Pacific Islands Plastic Pollution Policy Frameworks.

Sustainability 2021, 13, 1252. https:// doi.org/10.3390/su13031252

Academic Editor: Tony Robert Walker Received: 28 October 2020

Accepted: 8 January 2021

Published: 25 January 2021

Publisher's Note: MDPI stays neutral with regard to jurisdictional claims in published maps and institutional affiliations.

Copyright: (c) 2021 by the authors. Licensee MDPI, Basel, Switzerland. This article is an open access article distributed under the terms and conditions of the Creative Commons Attribution (CC BY) license (https:// creativecommons.org/licenses/by/ $4.0 /)$.

\begin{abstract}
The rate of plastic pollution entering the environment is accelerating with plastic production predicted to increase by $40 \%$ over the next decade. Plastic pollution transcends territorial boundaries on ocean and air currents. Large Ocean Small Island Developing States (LOSIDS) are on the frontline of the plastics crisis and associated climate change impacts. This desktop gap analysis identified potential strengths and weaknesses in national policy frameworks in 52 key documents relevant to plastic pollution in ten Pacific LOSIDS. The study found considerable gaps in the vertical and horizontal integration of plastic pollution-related policy, and a lack of access to current science-based evidence on plastic pollution including evidence related to human health impacts and microplastics. The study concludes that, even if Pacific LOSIDS were to include best practice management of plastic pollution across all policy frameworks, they could not prevent plastic pollution, and that a plastic pollution convention is needed.
\end{abstract}

Keywords: legislation; gap analysis; marine litter; microplastics; convention; waste management; large ocean islands; small island developing states

\section{Introduction}

Marine and human health, climate change and plastic pollution are mutually constituted global challenges. The physical and chemical impacts of plastic pollution on marine health are well documented from marine fauna ingestion, strangulation, suffocation and entanglement to the toxic impacts of plastics [1-3]. The latest estimate of mismanaged plastic waste entering the world's rivers, lakes and oceans is between 24 and 34 million metric tonnes (Mt) in 2020 [4]. With no action, this figure will increase to $36-90 \mathrm{Mt} \mathrm{y}^{-1}$ in 2030 [4]. Simultaneously, by the end of 2019, over US\$200 billion has been invested in hundreds of new chemical and plastics projects. Ninety-nine percent of plastics come from fossil fuels, and plastic production is estimated to produce $>400$ million tonnes of greenhouse gases (GHGs) per year. This figure does not include emissions from waste management (including transport), mismanagement, and degradation of plastic products [5]. By 2050, it is estimated that GHG emissions from plastics could reach over 56 gigatons: 10-13 percent of the entire remaining carbon budget [6]. Microplastic toxicity affects plankton development and reproduction. Since phytoplankton and zooplankton play a key role in primary productivity and the global carbon cycle, microplastic pollution impacts ocean carbon sequestration and climate change [7]. Any detrimental effects on phytoplankton and zooplankton threaten the entire ocean system and those who depend on it for medicine, food security, cultural identity, and wellbeing.

The Pacific Islands are identified by the United Nations (UN) as Small Island Developing States (SIDS) due to their "their small size, remoteness, narrow resource and export base, and exposure to global environmental challenges and external economic shocks, including to a large range of impacts from climate change and potentially more frequent and intense 
natural disasters" [8]. The Organization for Economic Co-operation and Development (OECD) adds the following economic vulnerabilities faced by SIDS: slow and volatile economic growth owing to strong sensitivity to natural disasters, capacity constraints due to dispersed populations which hamper the creation of sizable domestic markets, limited and challenging access and connectivity to international markets, a strong (overreliance) on tourism, and limited and dependent relationship with trading partners meaning greater exposure to "trade fragilities" [9]. Since the Ocean Conference in New York in June 2017, some SIDS (including countries in the Caribbean, the Pacific, and the Indian Ocean) now also refer to themselves as Large Ocean States (LOS) due to their significant share of Exclusive Economic Zones (EEZs), their vast coastlines, and their direct socioecological and economic connection to the ocean [10]. In this paper, therefore, we conceptualise Pacific Island countries as Large Ocean Small Island Developing states (LOSIDS), recognising the strengths of Pacific Island countries' EEZs while also acknowledging the increased plastic pollution vulnerabilities large EEZs present [11], and that these vulnerabilities are exacerbated by their SIDS status.

Pacific LOSIDS are exposed to marine plastic pollution disproportionate to their land area and domestic contributions. This is due to their position within the trade winds and at the outer edges of the Pacific Ocean gyre ([12]. Due to its propensity to flow freely across jurisdictional boundaries via air and tidal flows and trade routes, plastic pollution is one of many "wicked environmental problems" [13] (p. 183) facing Pacific LOSIDS [14]. Offshore sources of marine plastic debris including abandoned, lost or otherwise discarded fishing gear (ALDFG) carried on ocean currents from other nations can represent the most significant types of plastic debris contaminating Pacific LOSIDS' coastlines and waters [15] These remote and often low-lying island nations are dually vulnerable to plastic pollution and climate change as interrelated global crises.

Pacific LOSIDS have become dependent on a wide range of imported products (including plastics) but they are also dependent on a clean and healthy marine environment for their biophysical, economic, and cultural survival. As such, they have advocated for the prevention of plastic pollution, climate change, and the sustainable use of marine resources at global United Nations (UN) fora. For example, Pacific LOSIDS have been highly influential in the formulation of a standalone Sustainable Development Goal for the ocean (SDG 14) and in guiding the global narrative on climate change toward progressive action. Fiji announced voluntary commitments at the first UN Ocean Conference in 2017 to combat plastic pollution for the implementation of SDG 14 by pledging to ban single-use plastics [16]. In Pacific regional meetings, some leaders have put plastic pollution on an equal footing with climate change, calling for an urgent and coordinated global response (e.g., at the 2018 Pacific Island Forum Leaders' Meeting) [17]. There are several international conventions signed by Pacific LOSIDS that go some way to addressing plastic pollution and providing best practice principles. However, the United Nations Environment Programme's (UNEP) review of 18 international instruments and 36 regional instruments relevant to plastic pollution concludes that "current governance strategies and approaches provide a fragmented approach that does not adequately address marine plastic litter and microplastics" [18]. In response, researchers and international civil society organisations have called for an international plastic pollution convention [19-21].

This study explores the potential for an international plastic pollution convention by analysing ten Pacific LOSIDS' policy frameworks relevant to plastics. The analytic framework is an adaptation of the themes outlined in Pillar 2 (Plastic Pollution Prevention) of the Environmental Investigation Agency's (EIA) 'Pillars of Action': a proposed architecture for a new convention on plastic pollution. This framework provides the basis to identify strengths and weaknesses in Pacific LOSIDS national policy frameworks; areas where global coordination and support are needed for plastic pollution prevention in the region; and additional support Pacific LOSIDS may need from the international community to meet their obligations to a proposed international plastic pollution convention. The framework highlights international plastic pollution prevention best practice. Many of these practices 
are not applied in the Pacific region or may be adapted due to country/regional differences and context-specific challenges. This paper makes best practice and policy recommendations that may suit the study countries' LOSIDS status including where international cooperation and support are needed.

This study's analytic framework significantly widens the scope beyond marine-based litter to consider impacts along the full life cycle of plastics from extraction to waste management/mismanagement including impacts on air, water (marine and freshwater), human and non-human health, and soil. The study focus is not on managing plastic debris washing up on coastlines. There is no country in the world with a coastline that can stop plastics washing up on their shores and contaminating marine ecologies from point sources in countries located often thousands of miles away-particularly once those plastics have fragmented into micro and nano-sized fragments. Instead, the study focusses on preventing the inflow of plastic into the region via trade and tourism because these are the only points of entry any country has any control over, limited though this may be in the absence of a global agreement.

The findings highlight limitations in preventing plastic pollution at the national level, including Pacific LOSIDS' readiness to transpose a proposed multilateral plastic pollution convention into current national policy frameworks, and potential to strengthen those frameworks. Literature concerned with the prevention and mitigation of 'marine litter' is generally focused on a limited set of harms caused by the physical properties of plastics including coral reef and marine vessel damage, and fauna entanglement and ingestion. Our analysis is focused on a comprehensive 'full life cycle' understanding of the harms of plastic pollution including harms caused by the toxic constituents of plastics, the impacts these can have on biological communities, and climate change-induced plastic pollution (climate change affected by pollution caused at every point along the lifecycle of plastics). This includes plastic pollution and pollutants emitted from waste management technologies and bio/degradable plastics. The chemical (fossil fuel and bio-based) hazards include monomers (the building blocks of plastic polymers) and additives (such as plasticisers, flame retardants, and stabilizers). The analysis also captures the risks borne by associated chemicals such as persistent organic pollutants (POPs) adsorbed by hydrophobic plastics, furans and dioxins released when plastics are burned, and the methane and chlorine plastics 'off gas' during degradation [5]. Waste management technologies such as chemical recycling, downcycling (e.g., plastic roading), and waste-to-energy incineration also emit pollutants. This study considers associated organisms or novel ecosystems including the pathogens and invasive species that can raft on plastics threatening biodiversity, and food safety and security. Plastics alternatives (such as bio/degradable plastics) are also captured in this study as they share the same fates as traditional fossil fuel-based plastic pollution. Additionally, the production or extraction of plastic alternative feedstocks can also pollute and present social injustices.

\section{Materials and Methods}

Gap analysis is a common technique used to illustrate the difference between the status quo and a reference model or proposed state [22]. Therefore, gap analyses are rarely singular in their aim as they generally ask two basic questions: What is the current situation? How could the situation be improved? This gap analysis involved desktop research of publicly available online resources (Appendix A). The analysis compared current national plastic pollution policy frameworks in the Pacific Islands region with an analytical framework developed by the researchers which were largely based on 'Pillar Two: Plastic Pollution Prevention' of the Environmental Investigation Agency's (EIA's) proposed 'Pillars of Action' [20]. The Pillars of Action are the architecture for a proposed Convention on Plastic Pollution. These Pillars present the areas identified by United Nations member states and non-state experts via the United Nations Ad Hoc Expert Group (AHEG) meetings and United Nations Environment Assemblies (UNEA) where activities are needed to prevent global plastic pollution. The final and expanded analytical framework (Table 1) 
was adapted iteratively through preliminary document analysis, regular research team discussions, and guidance of key documents $[18,20,23]$. By comparing the policy frameworks of ten countries in the Pacific region with our more granular and expanded adaptation of Pillar 2, we found weaknesses in the ability of Pacific LOSIDS to protect themselves from plastic pollution and to promote a safe circular plastics economy. The study also highlights where globally coordinated efforts are needed to support the region in plastic pollution prevention. EIA's Pillars provide a meta-level framework for a potential plastic pollution prevention convention. Additional subcategories emerged out of the iterative coding process providing a more granular analysis and insights into national specificities. The resulting analytic framework may be useful in analysing the plastic pollution policy frameworks of other LOSIDS. As such, an additional eight sub-themes have been added to EIA's 'long-term elimination of discharges' and 'safe circular economy for plastics' under this category (Table 1). For example, 'International and Regional Commitments' located under National Action Plans in EIA's Pillar 2 appears as 'Vertical Integration' under 'Global Objectives' as a cross-cutting theme. 'Horizontal Integration' has also been added to 'Global Objectives' to capture the level of inter-ministerial integration and cohesion evidenced across all documents analysed.

National actions most likely to prevent the flow of plastics into the economy are categorised as 'Waste Prevention'. Virgin plastics are not produced in Pacific LOSIDS, so the theme, 'Reduction in Virgin Plastics' here relates to the use of virgin plastics for manufacturing plastic products in the study countries. Actions that contribute to the prevention of further damage once plastics have already entered the environment appear under 'Waste Management'. EIA's Pillar 2: Plastic Pollution Prevention includes the category 'national action plans' under which sits the theme, 'Targets and Market Restrictions'. 'Targets' appears as a separate theme in this study: 'National Reduction Targets'. 'Market restrictions' are split into two themes: 'Trade in Non-Hazardous Recyclable and Reusable Plastics' and 'Market Restrictions' to allow for the examination of import and domestic trade measures.

'Waste Prevention and Management' appears in this study as separate major categories. 'Recycling and Secondary Markets' are separately analysed under the major category 'Waste Management' as 'Closed Loop Recycling (Primary Market) or Secondary Markets'. Elements of this category have also been cross-referenced in the major category 'Prevention' under 'Trade in Non-Hazardous, Recyclable, and Reusable Plastics' and 'Sustainable Financing Mechanisms/Market-Based Instruments'. 'Infrastructure Investments' are spread across the 'Management' major category and 'International and Regional Commitments' are captured under the 'Global Objectives' major heading as 'Vertical Integration'. In this study, 'Remediation and Legacy Pollution' (Protocols and Guidelines) is interpreted as examples of 'Management' responses. 'Transport' also emerged as an additional key theme under 'Management'.

'Agriplastics' have been included under 'Microplastics' to capture microplastics found in agricultural products such as slow-release fertilisers. 'Product Design and Additive Restrictions' are separated under the major category 'Standardisation'. Themes additional to EIA's Pillar 2 under 'Standardisation' include 'Polymer Restrictions' ‘Mandatory Product Stewardship', 'National Monitoring, Reporting and Inventories', 'Transparency and Freedom of Information', 'Enforcement' (since monitoring and reporting compliance are minimum requirements of enforcement), and standardised 'Definitions'.

The countries included in the gap analysis (hereafter referred to as the 'study countries') are geographically representative of the Pacific region, and actively participate in the UNEA Marine Litter and Microplastics Resolution process including AHEG and other intersessional meetings. Further, these countries have expressed interest in, or outright support for, a plastic pollution convention and, therefore, were willing participants in this study:

- Melanesia: The Republic of Fiji, Papua New Guinea, Solomon Islands, Vanuatu

- Polynesia: The Independent State of Samoa, the Kingdom of Tonga, Tuvalu

- Micronesia: The Republic of Kiribati, the Republic of the Marshall Islands, the Republic of Palau. 
Table 1. Analytical framework including the categories, themes and definitions based on the Environmental Investigation Agency's (EIA) Pillars of Action and supporting documents.

\begin{tabular}{ccc}
\hline Category & Themes & Definition \\
\hline & $\begin{array}{c}\text { Long-term Elimination of } \\
\text { Discharges }\end{array}$ & Sustainable, Long-term Solutions.
\end{tabular}

A circular economy has minimal waste and reuses raw materials again and again. Any materials circulating in the economy are safe by design,

Safe circular economy for plastics allowing their introduction into the economy and their reuse without risks for human health and the environment. This includes keeping 'substances of very high concern' (e.g., POPs as plastic additives) out of the circular economy and ultimately aims to eliminate them entirely.

Intergenerational equity Ensures future generations flourish as a result of the current and justice policy, legislation and action.

Progresses the UN Sustainable Development Goals:

Target 3: Good health and well-being

Target 6: Clean water and sanitation

SDGs

Target 11: Sustainable cities and communities

Target 12: Responsible consumption and production Target 13: Climate action

Global objectives

Target 14: Life below water (protection of the seas and oceans)

Target 15: Life on land (restore ecosystems and preserve diversity).

The connection between plastics and human health is explicit and/or

Protection of human health provisions made.

\begin{tabular}{cr}
\hline Vertical integration & Responds to regional and international obligations. \\
\hline Horizontal Integration & $\begin{array}{r}\text { Evidence of coherence between legislation, and national policies, } \\
\text { plans and strategies (inter-ministerial cooperation). }\end{array}$ \\
\hline Precautionary approach & $\begin{array}{r}\text { Lack of scientific data or certainty is not a reason for not acting to } \\
\text { prevent serious or irreversible damage. }\end{array}$ \\
\hline
\end{tabular}

\begin{tabular}{cc}
\hline Waste hierarchy & $\begin{array}{c}\text { There is either explicit reference to the waste hierarchy and/or a focus } \\
\text { on the top of the waste hierarchy (refuse, reduce, reuse, redesign). }\end{array}$ \\
\hline Climate Change & $\begin{array}{r}\text { The connection between plastic pollution and climate change is made } \\
\text { explicit and/or provisions are made. }\end{array}$ \\
\hline
\end{tabular}

Trade in non-hazardous, recyclable and reusable plastics

Import and export bans and restrictions, minimum environmental standards for plastics imports and exports, fees on problematic imported plastic.

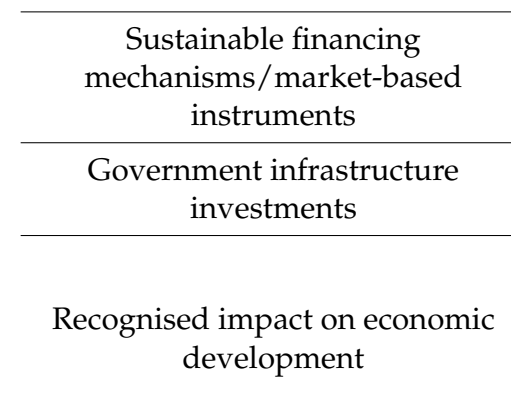

Examples include waste-management fees, deposit-refund schemes, extended producer responsibility (EPR) schemes, licensing schemes, plastic taxes and levies, advanced disposal fees, polluter pays, and user pays.

The government invests in accessible and regular separate waste collection, recycling, reuse, and preventative measures.

An explicit link is made between the impact of plastic pollution on economic development (e.g., tourism, safe and secure employment

Waste prevention development opportunities, agriculture). This might also factor in the economic cost of not preventing plastic pollution/inaction. Plastic pollution is presented as a potential business risk.

\begin{tabular}{cc}
\hline National reduction targets & Measurable plastic pollution reduction targets and timelines. \\
\hline Virgin plastic use & Controls and standards to reduce virgin plastics entering the economy \\
(e.g., caps).
\end{tabular}


Table 1. Cont.

\begin{tabular}{|c|c|c|}
\hline Category & Themes & Definition \\
\hline \multirow{3}{*}{ Waste management } & $\begin{array}{l}\text { Closed-loop recycling (primary } \\
\text { market) or secondary markets }\end{array}$ & $\begin{array}{l}\text { Secondary ('cascade' markets) recycling is also known as 'downcycling' } \\
\text { from a higher value product to a lower grade product, e.g., from a PET } \\
\text { bottle into a less/non- recyclable product such as carpet. }\end{array}$ \\
\hline & Remediation and legacy pollution & $\begin{array}{l}\text { Includes protocols and guidelines to recover legacy plastics (e.g., } \\
\text { marine debris) to be safely reused, recycled or repurposed and } \\
\text { remediation of landfills (e.g., following storm damage). }\end{array}$ \\
\hline & Transport & $\begin{array}{l}\text { Transport infrastructure; access; port capacity; backloading (filling } \\
\text { empty trucks and/or shipping containers with waste on their return to } \\
\text { point of origin/producers); and reverse logistics (shipping the product } \\
\text { back to the producer post-consumption for recycling or reuse). }\end{array}$ \\
\hline \multirow{4}{*}{ Microplastics } & $\begin{array}{l}\text { Intentionally added } \\
\text { (e.g., microbeads) }\end{array}$ & $\begin{array}{l}\text { Restrictions on the importation and trade of products with } \\
\text { added microbeads. }\end{array}$ \\
\hline & Wear and tear (e.g., tyres, textiles) & $\begin{array}{l}\text { Restrictions on the importation of plastic products with high } \\
\text { wear and tear. }\end{array}$ \\
\hline & Agriplastics & $\begin{array}{l}\text { Management and prevention of plastics used in agriculture such as } \\
\text { plastic mulch and microbeads in controlled-release fertilizers. }\end{array}$ \\
\hline & Management (e.g., pellets) & Handling guidelines or restrictions. \\
\hline \multirow{9}{*}{ Standardisation } & Product design & Eco- and bio- benign product design. \\
\hline & Polymer restrictions & Restrictions on the importation and trade of certain polymers. \\
\hline & Additive restrictions & $\begin{array}{l}\text { Restrictions on the importation and use of toxic additives and } \\
\text { monomers, such as those categorised as EDCs, POPs, and carcinogens. }\end{array}$ \\
\hline & $\begin{array}{l}\text { Voluntary certification schemes } \\
\text { and industry standards }\end{array}$ & $\begin{array}{c}\text { Compliance to certification schemes such as ISO for home } \\
\text { compost-ability; and products and services certified 'zero waste to } \\
\text { landfill'. Businesses commit to reducing plastics throughout } \\
\text { their supply chain. }\end{array}$ \\
\hline & Mandatory product stewardship & $\begin{array}{l}\text { Government mandated participation in accredited schemes for the } \\
\text { stewardship of plastic products. }\end{array}$ \\
\hline & $\begin{array}{l}\text { National monitoring and } \\
\text { reporting, national inventories } \\
\text { and reduction targets }\end{array}$ & $\begin{array}{l}\text { Tracking of production, trade, consumption, and recycled content, } \\
\text { final treatment. National reduction targets with agreed timelines. }\end{array}$ \\
\hline & $\begin{array}{l}\text { Transparency and Freedom of } \\
\text { information (consumer } \\
\text { justice, labelling) }\end{array}$ & $\begin{array}{l}\text { Information is readily available to the consumer. Information could } \\
\text { include recycled content, recyclability, appropriate disposal, } \\
\text { compost-ability, additives, GHGs, and hazard potential. }\end{array}$ \\
\hline & $\begin{array}{l}\text { Compliance measures } \\
\text { (monitoring and reporting) } \\
\text { and enforcement }\end{array}$ & $\begin{array}{l}\text { Minimum requirements, monitoring and reporting. Mechanisms for } \\
\text { managing suspected or identified instances of non-compliance such as } \\
\text { financial penalties, imprisonment, or confiscation. }\end{array}$ \\
\hline & Definitions & $\begin{array}{l}\text { Standardised definitions, e.g., 'reusable', 'compostable', } \\
\text { 'recyclable', 'biodegradable'. }\end{array}$ \\
\hline
\end{tabular}

The documents analysed (Appendix A) were limited to country-level legislation, policies, plans and strategies relevant to plastic pollution. Additional documents were cross-referenced to ensure the most current relevant documents were captured (Appendix B). The gap analysis review process comprised of five components:

1. Keyword search of documents. Documents were searched for the following terms: 'waste', 'plastic', 'refuse', 'garbage', 'litter', 'pollution', 'microplastic', 'marine debris', 'hazardous waste', 'emission', and 'contaminant' for references to plastic pollution.

2. Documents were reviewed to determine whether its instruments and mechanisms for plastic pollution focused on the top of the waste hierarchy: refuse, rethink, reduce, redesign, and reuse. From this, a set of documents were determined 'key' to preventing plastic pollution in each country. 
3. Next, a granular thematic analysis of the key documents was undertaken using the key words and themes derived from the analytical framework (Table 1). Synonyms and synonymic phrases in the themes were examined for their application within and across national legislation, policies, and plans.

4. Based on the definitions provided in the analytical framework (Table 1), green indicates explicit mention of the theme in the document, yellow indicates that the document either partially includes the theme or that it is inferred and red indicates that that the theme is absent in the document.

5. Country delegates were emailed to request validation of the selected documents and the study was validated through an internal peer review process.

Gap analyses implicitly or explicitly involve benchmarking [22]. That is, using others' knowledge and experience for future improvements, analysing one's own performances, highlighting strengths and weaknesses, and assessing what needs to be done to improve any given situation. EIA's Pillars of Action are modelled on recommendations from the UN Member States at AHEG Meetings, UN Scientific Advisory Committee (SAC) meetings (Marine Litter and Microplastics), and UNEAs over the last two years. Therefore, this adaptation of the Pillars of Action offers is a heuristic device for Pacific LOSIDS to determine their own priorities and (as the study shows) which response options are beyond their resources and capacity and will require the support of the global community.

\section{Results}

The following highlight the key findings of the study. Note that not all 34 themes will be presented in this section. While all the themes are crucial to plastic pollution prevention, we have focused on developing the themes that are most relevant to/attainable for Pacific LOSIDS.

\subsection{Global Objectives}

The following global objectives (Table 2) can build a coherent narrative of what is broadly required to attain the shared goal of plastic pollution prevention.

\subsubsection{Vertical Integration}

Policy alignment is the alignment of international, national and subnational policies [24]. The goal of vertical integration or alignment is to ensure that national level policies are consistent with regional and international level policies. Vertical policy alignment occurs when the international and regional policy, strategies, and agreements are adapted and integrated into national policy frameworks. Strengthening vertical integration can enhance overall coherence and coordination towards mutual and reinforcing goals [25].

The relevant legislation and national plans and strategies rarely reflect the international agreements and regional instruments (Appendix A) that the study countries have signed, ratified or acceded, relevant to plastic pollution (Table 2).

Tables 3 and 4 illustrate the international agreements and regional instruments the study countries have signed, ratified or acceded to that are relevant to plastic pollution. The international and regional obligations relevant to plastic pollution are acknowledged in many country-level documents. However, the relevant legislation and national plans and strategies rarely reflect those obligations (Table 2). For example, Samoa's $\mathrm{Na}$ tional Implementation Plan for Persistent Organic Pollutants 2004 is 16 years old and provides the implementation plan for actions that address a now obsolete national Waste Management Strategy. 


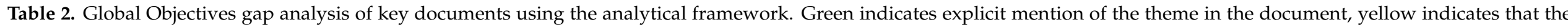
document either partially includes the theme or that it is inferred and red indicates that that theme is absent in the document.

\begin{tabular}{|c|c|c|c|c|c|c|c|c|c|c|c|}
\hline & Legislation & $\begin{array}{c}\text { Long-term } \\
\text { Elimination of } \\
\text { Discharges } \\
\end{array}$ & $\begin{array}{c}\text { Safe Circular } \\
\text { Economy for } \\
\text { Plastics } \\
\end{array}$ & $\begin{array}{l}\text { Intergenerational } \\
\text { Equity and } \\
\text { Justice }\end{array}$ & SDGs & $\begin{array}{l}\text { Protection of } \\
\text { Human Health }\end{array}$ & $\begin{array}{l}\text { Vertical } \\
\text { Integration }\end{array}$ & $\begin{array}{l}\text { Horizontal } \\
\text { Integration }\end{array}$ & $\begin{array}{l}\text { Precautionary } \\
\text { Approach }\end{array}$ & $\begin{array}{c}\text { Waste } \\
\text { Hierarchy }\end{array}$ & $\begin{array}{l}\text { Climate } \\
\text { Change }\end{array}$ \\
\hline \multirow{5}{*}{ Fiji } & $\begin{array}{l}\text { Environment Management Act } 2005 \text { Amendments and } \\
\text { Regulations } 24 \text { June } 2019\end{array}$ & & & & & & & & & & \\
\hline & Litter Act 2008 and Litter (Amendment) Act (2010) & & & & & & & & & & \\
\hline & $\begin{array}{l}\text { Public Health Act } 1935 \text { including Public Health } \\
\text { Regulations } 1937 \text { (as at } 1 \text { August 2018) [PHA 128]; } \\
\text { and Public Health and Sanitary Services } \\
\text { Regulations } 1941\end{array}$ & & & & & & & & & & \\
\hline & Climate Change Bill 2019 & & & & & & & & & & \\
\hline & $\begin{array}{l}\text { Fiji National Solid Waste Management } \\
\text { Strategy 2011-2014 }\end{array}$ & & & & & & & & & & \\
\hline \multirow{5}{*}{ Kiribati } & Environment (Amendment) Act 2007 & & & & & & & & & & \\
\hline & Special Fund (Waste Materials Recovery) Act 2004 & & & & & & & & & & \\
\hline & Kiribati Solid Waste Management Plan (KSWMP) & & & & & & & & & & \\
\hline & Kiribati 20-year Vision 2016-2036 or KV20 & & & & & & & & & & \\
\hline & Kiribati Development Plan 2016-2019 & & & & & & & & & & \\
\hline \multirow{3}{*}{$\begin{array}{l}\text { Marshall } \\
\text { Islands }\end{array}$} & $\begin{array}{l}\text { Styrofoam cups and plates, and plastic products } \\
\text { prohibition, and container deposit Act } 2016\end{array}$ & & & & & & & & & & \\
\hline & National Environment Management Strategy 2017-2022 & & & & & & & & & & \\
\hline & $\begin{array}{l}\text { Kwajalein Atoll Local Government Solid Waste } \\
\text { Management Plan 2019-2028 }\end{array}$ & & & & & & & & & & \\
\hline \multirow{5}{*}{ Palau } & National Code: Title 24: Environmental Protection & & & & & & & & & & \\
\hline & The Recycling Act 2006 (including 2009 Amendments) & & & & & & & & & & \\
\hline & Plastic Bag Use Reduction Act 2017 & & & & & & & & & & \\
\hline & Zero Disposable Plastic Policy, Executive Order No. 417 & & & & & & & & & & \\
\hline & $\begin{array}{l}\text { The National Solid Waste Management Strategy: } \\
\text { the roadmap towards a clean and safe Palau 2017-2026 }\end{array}$ & & & & & & & & & & \\
\hline \multirow{4}{*}{$\begin{array}{l}\text { Papua } \\
\text { New Guinea }\end{array}$} & Environmental Contaminants Act 1978 & & & & & & & & & & \\
\hline & Environment Act 2000 & & & & & & & & & & \\
\hline & Public Health Act 1973 & & & & & & & & & & \\
\hline & STaR & & & & & & & & & & \\
\hline
\end{tabular}


Table 2. Cont.

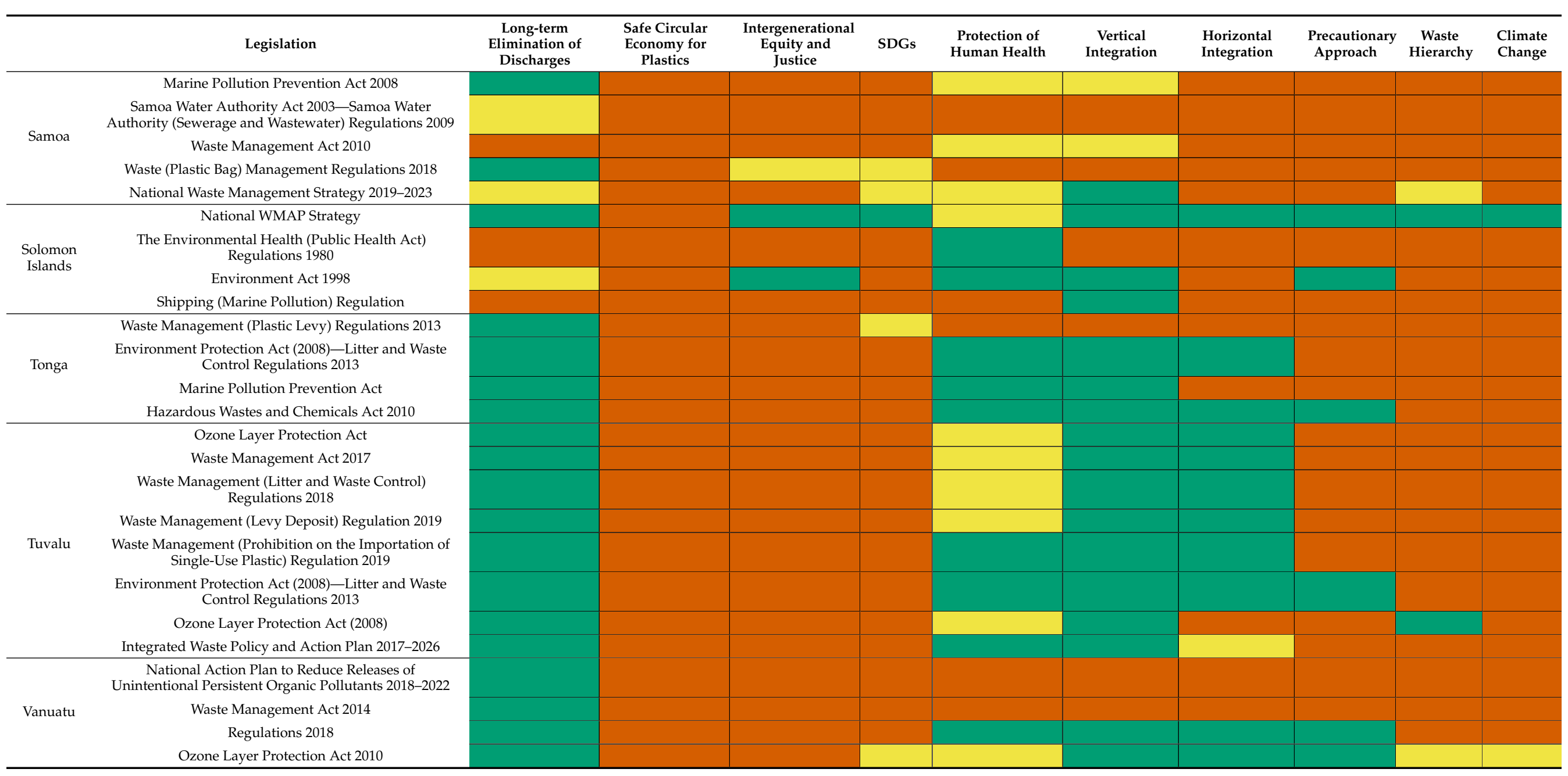




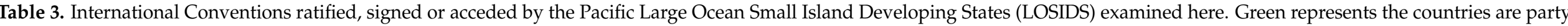
to the agreement, yellow that they have participated and/or acknowledged they will sign (but have not yet).

\begin{tabular}{|c|c|c|c|c|c|c|c|c|c|c|c|}
\hline International Agreements & Description & Fiji & Kiribati & $\begin{array}{l}\text { Marshall } \\
\text { Islands }\end{array}$ & Palau & $\begin{array}{l}\text { Papua New } \\
\text { Guinea }\end{array}$ & Samoa & $\begin{array}{c}\text { Solomon } \\
\text { Islands }\end{array}$ & Tonga & Tuvalu & Vanuatu \\
\hline $\begin{array}{l}\text { UNCLOS-United Nations } \\
\text { Convention on the Law of } \\
\text { the Sea (1982) }\end{array}$ & $\begin{array}{l}\text { Legally binding global instrument for the } \\
\text { protection of the marine environment from all } \\
\text { sources of pollution. }\end{array}$ & & & & & & & & & & \\
\hline MARPOL 73/78 Annex V & $\begin{array}{l}\text { Legally binding global instrument to prevent } \\
\text { marine pollution from ships (Annex } V \text {-Prevention } \\
\text { of pollution by garbage from ships (includes all } \\
\text { plastics and fishing gear) }\end{array}$ & & & & & & & & & & \\
\hline $\begin{array}{l}\text { London Convention } \\
72 \text { (“Convention on the } \\
\text { Prevention of Marine } \\
\text { Pollution by Dumping of } \\
\text { Wastes and other Matter") } \\
\end{array}$ & $\begin{array}{l}\text { Legally binding global instrument listing } \\
\text { prohibited pollutants and those requiring permits } \\
\text { for dumping (intentional dumping into the sea) }\end{array}$ & & & & & & & & & & \\
\hline $\begin{array}{l}\text { London Convention } \\
\quad \text { Protocol } 96\end{array}$ & $\begin{array}{l}\text { Legally binding agreement for the Prevention of } \\
\text { Marine Pollution by Dumping of Wastes and Other } \\
\text { Matter (1996) }\end{array}$ & & & & & & & & & & \\
\hline $\begin{array}{l}\text { Conservation Management } \\
\text { Measure on Marine } \\
\text { Pollution (2019) }\end{array}$ & $\begin{array}{l}\text { Prevent and significantly reduce marine pollution } \\
\text { of all kinds to Support the Implementation of } \\
\text { Sustainable Development Goal 14, International } \\
\text { Convention for the Prevention of Pollution from } \\
\text { Ships (MARPOL) Annex V, London Convention } \\
\text { and London Protocol. }\end{array}$ & & & & & & & & & & \\
\hline Intervention Protocol 73 & $\begin{array}{l}\text { Concerning pollutants other than oil in the } \\
\text { high seas. }\end{array}$ & & & & & & & & & & \\
\hline $\begin{array}{l}\text { The } 2030 \text { Agenda for } \\
\text { Sustainable Development } \\
\text { (SDGs) }\end{array}$ & Broad scope including pollution management. & & & & & & & & & & \\
\hline $\begin{array}{c}\text { Basel } \\
\text { Convention } 1992 \text { (Plastic } \\
\text { Waste Amendments) }\end{array}$ & $\begin{array}{l}\text { Legally binding global instrument on the } \\
\text { transboundary movement of hazardous wastes and } \\
\text { other wastes (plastics as other wastes). }\end{array}$ & & & & & & & & & & \\
\hline $\begin{array}{l}\text { Stockholm Convention } \\
(2004)\end{array}$ & $\begin{array}{l}\text { Legally binding global instrument to control } \\
\text { persistent organic pollutants. }\end{array}$ & & & & & & & & & & \\
\hline $\begin{array}{l}\text { Rotterdam Convention } \\
\qquad(2004)\end{array}$ & $\begin{array}{l}\text { The Convention creates legally binding obligations } \\
\text { for the implementation of prior informed consent in } \\
\text { the trade of hazardous waste. } 2019 \text { decisions to } \\
\text { protect human health and the environment from the } \\
\text { harmful effects of chemicals and wastes, including } \\
\text { plastic waste. }\end{array}$ & & & & & & & & & & \\
\hline
\end{tabular}


Table 3. Cont.

\begin{tabular}{|c|c|c|c|c|c|c|c|c|c|c|c|}
\hline International Agreements & Description & Fiji & Kiribati & $\begin{array}{l}\text { Marshall } \\
\text { Islands }\end{array}$ & Palau & $\begin{array}{c}\text { Papua New } \\
\text { Guinea }\end{array}$ & Samoa & $\begin{array}{l}\text { Solomon } \\
\text { Islands }\end{array}$ & Tonga & Tuvalu & Vanuatu \\
\hline $\begin{array}{l}\text { International Convention } \\
\text { for the Control and } \\
\text { Management of Ships' } \\
\text { Ballast Water and Sediments } \\
\text { (BWM) } 2004\end{array}$ & $\begin{array}{l}\text { Adopted in 2004. Aims to prevent the spread of } \\
\text { harmful aquatic organisms from one region to } \\
\text { another by establishing standards and procedures } \\
\text { for the management and control of ships' ballast } \\
\text { water and sediments. }\end{array}$ & & & & & & & & & & \\
\hline Nairobi WRC (2007) & $\begin{array}{l}\text { A legal basis for coastal states to remove wrecks } \\
\text { which pose a hazard to the safety of navigation or } \\
\text { to the marine and coastal environments. Covers } \\
\text { prevention, mitigation or elimination of hazards } \\
\text { created by any object lost at sea from a ship (e.g., } \\
\text { lost containers). }\end{array}$ & & & & & & & & & & \\
\hline $\begin{array}{l}\text { Hong Kong Convention } \\
\text { (2009) }\end{array}$ & $\begin{array}{l}\text { Aimed at ensuring that ships do not pose any } \\
\text { unnecessary risk to human health and safety or to } \\
\text { the environment when recycled after reaching the } \\
\text { end of their operational lives. }\end{array}$ & & & & & & & & & & \\
\hline $\begin{array}{l}\text { United Nations Framework } \\
\text { Convention on Climate } \\
\text { Change (UNFCCC) (1992) }\end{array}$ & Climate change convention 1993 & & & & & & & & & & \\
\hline Montreal Protocol (1987) & $\begin{array}{l}\text { Designed to protect the ozone layer by phasing out } \\
\text { the production of numerous substances responsible } \\
\text { for ozone depletion. }\end{array}$ & & & & & & & & & & \\
\hline \multicolumn{12}{|l|}{$\begin{array}{l}\text { Vienna Convention on the } \\
\text { Protection of the Ozone } \\
\text { Layer }\end{array}$} \\
\hline \multicolumn{12}{|l|}{ Strategies } \\
\hline $\begin{array}{l}\text { The Honolulu Strategy } \\
\text { (2011) }\end{array}$ & $\begin{array}{l}\text { A global framework for prevention and } \\
\text { management of marine debris including land and } \\
\text { sea-based sources }\end{array}$ & & & & & & & & & & \\
\hline
\end{tabular}


Table 4. Regional Instruments ratified, signed or acceded by the Pacific LOSIDS examined here. Green represents the countries are party to the agreement.

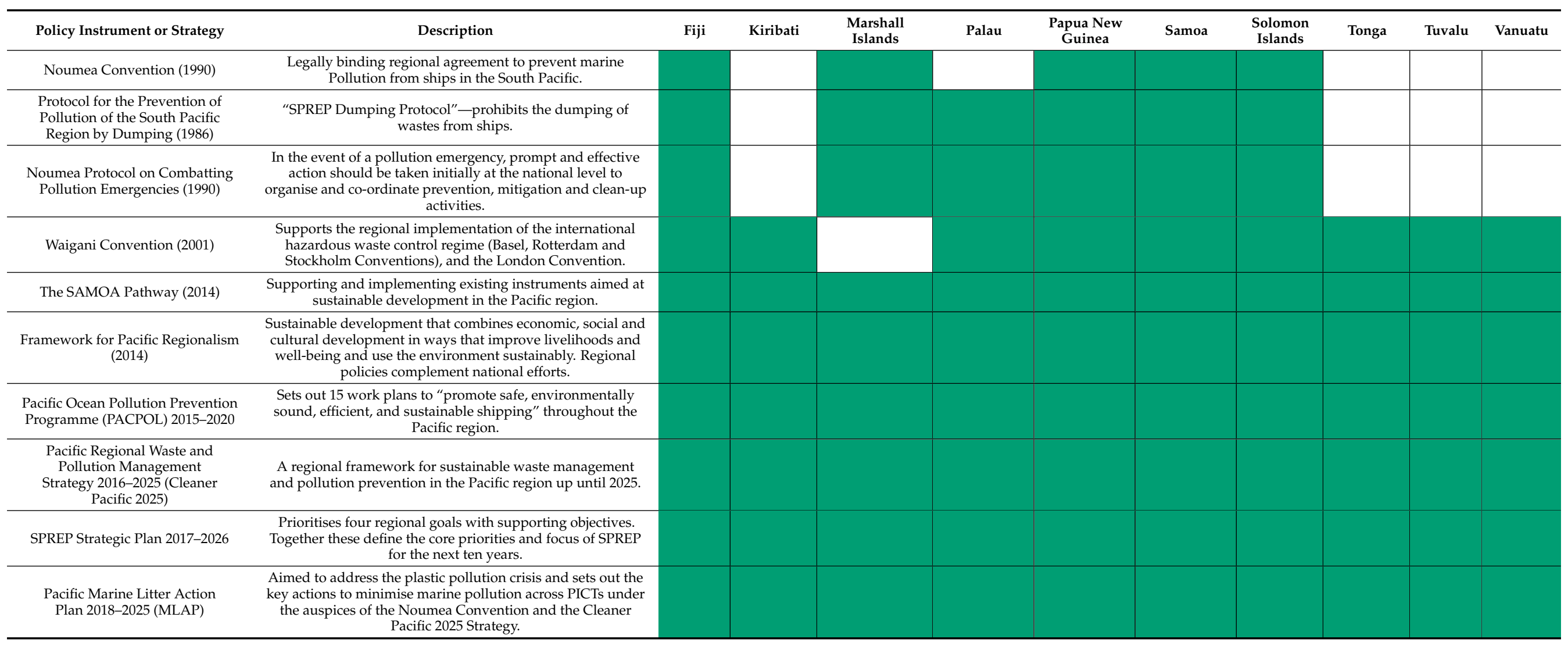




\subsubsection{Horizontal Integration}

Like vertical integration, the main goal of horizontal alignment is consistency across national policies, legislation, and plans. This creates coherence among policies and increases the potential to meet overarching goals [26]. Success in mitigating complex problems such as plastic pollution relies on inter-ministerial coordination [25-29]. 'Horizontal Integration' in Table 4 indicates whether a specific document references at least one other ministerial document or ministry. Horizontal integration is reflected in the seventh guiding principle of Palau's Solid Waste Strategy-the multi-sectoral approach: "Waste management and pollution control approaches shall involve multiple sectors (such as climate change, biodiversity conservation, health, tourism and agriculture) in order to improve the success and effectiveness of interventions". Yet, a deeper analysis of these documents suggests that this criterion does not necessarily lead to a cohesive and coherent policy framework for plastic pollution. For example, broader environmental management plans and strategies may present waste in specific sections but not as a cross-cutting theme (for example, Samoa's National Environment Sector Plan 2017-2021). In addition, each document may reference a range of ministerial departments, but this does not create a unified policy framework for solid waste management, nor for plastic pollution more specifically.

\subsubsection{Protection of Human Health}

Policy protecting human health from the hazards of plastics cannot exist if these hazards are unknown to policymakers. Plastics can present hazards to human health all along the supply chain [30-32]. However, the full range of known harms plastics can present to human health are not been captured in any of the documents analysed. Consequently, there are few legislative provisions that protect Pacific peoples from these harms.

Most of the documents in this study offer protections for human health only in relation to waste control (Table 5). This is limited to the physical properties of plastic as 'waste' or 'litter' rather than harms associated with plastic food contact materials, microand nano-plastics, food and beverage contamination, POPs, monomers and additives, waste treatment technologies and the contamination of agricultural soil, air, and fishing areas. The only health concerns related to plastics present in many of the documents studied were that discarded plastics offer ideal conditions for mosquito breeding which can act as vectors for diseases such as dengue fever, or that burning plastics could cause respiratory disease.

Plastics are seldom recognised as specific materials that present a unique set of harmful properties and fates all along their full life cycle. For example, plastic packaging can leach endocrine-disrupting chemicals (EDCs) and carcinogens into food and beverages $[33,34]$. Conventional disposable sanitary products are made from up to 90 percent ethane (a known EDC). The only legislation that acknowledges this risk is Palau's Plastic Bag Use Reduction Act, RPPL No. 10-14 2017. Alternatively, Tuvalu's Waste Management (Levy Deposit) Regulations consider disposable sanitary products of low risk to human health: "As long as the waste is suitably wrapped, properly handled and free from residual liquids, the risk to human health is considered low" (Part II, 10 (c) p. 6).

\subsubsection{Climate Change}

When burnt, plastics release dioxins and furans, polychlorinated biphenyls (PCBs) and GHGs. Plastics can also release methane (a GHG) and chlorine (an ozone-depleting chemical) as they break down [5]. Some waste management legislation does reference the impacts of burning waste on the ozone layer, but plastics are rarely specified. Palau's Air Pollution Control Regulations are unique in this respect as they specify plastics, including tyres, rubber products, and packaging waste, in a list of waste materials prohibited from open burning. 


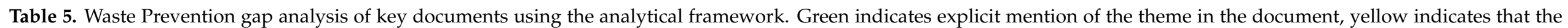
document either partially includes the theme or that it is inferred and red indicates that that theme is absent in the document.

\begin{tabular}{|c|c|c|c|c|c|c|c|c|c|}
\hline Country & Legislation & $\begin{array}{l}\text { Trade in } \\
\text { Non-hazardous, } \\
\text { Recyclable and } \\
\text { Reusable } \\
\text { Plastics }\end{array}$ & $\begin{array}{l}\text { Legal Basis for } \\
\text { Sustainable } \\
\text { Financing } \\
\text { Mechanisms }\end{array}$ & $\begin{array}{l}\text { Infrastructure } \\
\text { Investments }\end{array}$ & $\begin{array}{l}\text { Economic } \\
\text { Development/ } \\
\text { Legal Basis for Loss } \\
\text { or Damage }\end{array}$ & $\begin{array}{c}\text { National } \\
\text { Reduction Targets }\end{array}$ & $\begin{array}{l}\text { Virgin Plastic } \\
\text { Use }\end{array}$ & $\begin{array}{c}\text { Market } \\
\text { Restrictions }\end{array}$ & $\begin{array}{l}\text { Promotion of } \\
\text { Traditional } \\
\text { Solutions }\end{array}$ \\
\hline \multirow{6}{*}{ Fiji } & $\begin{array}{l}\text { Environment Management Act } 2005 \text { / Amendments } \\
\text { and Regulations } 24 \text { June } 2019\end{array}$ & & & & & & & & \\
\hline & Litter Act 2008 and Litter (Amendment) Act (2010) & & & & & & & & \\
\hline & $\begin{array}{c}\text { Public Health Act } 1935 \text { including Public Health } \\
\text { Regulations } 1937 \text { (as at } 1 \text { August 2018) [PHA 128]; } \\
\text { and Public Health and Sanitary Services } \\
\text { Regulations } 1941\end{array}$ & & & & & & & & \\
\hline & Climate Change Bill 2019 & & & & & & & & \\
\hline & Republic of Fiji Climate Change Policy 2012 & & & & & & & & \\
\hline & $\begin{array}{c}\text { Fiji National Solid Waste Management } \\
\text { Strategy 2011-2014 }\end{array}$ & & & & & & & & \\
\hline \multirow{5}{*}{ Kiribati } & Environment (Amendment) Act 2007 & & & & & & & & \\
\hline & Special Fund (Waste Materials Recovery) Act 2004 & & & & & & & & \\
\hline & Kiribati Solid Waste Management Plan (KSWMP) & & & & & & & & \\
\hline & Kiribati 20-year Vision 2016-2036 or KV20 & & & & & & & & \\
\hline & Kiribati Development Plan 2016-2019 & & & & & & & & \\
\hline \multirow[t]{3}{*}{$\begin{array}{l}\text { Marshall } \\
\text { Islands }\end{array}$} & $\begin{array}{c}\text { Styrofoam Cups and Plates, and Plastic Products } \\
\text { Prohibition Container Deposit (Amendment) } \\
\text { Act, } 2018 \text { (2018-0054) }\end{array}$ & & & & & & & & \\
\hline & National Environment Management Strategy 2017-2022 & & & & & & & & \\
\hline & $\begin{array}{l}\text { Kwajalein Atoll Local Government Solid Waste } \\
\text { Management Plan 2019-2028 }\end{array}$ & & & & & & & & \\
\hline \multirow{5}{*}{ Palau } & National Code: Title 24: Environmental Protection & & & & & & & & \\
\hline & The Recycling Act 2006 (including 2009 Amendments) & & & & & & & & \\
\hline & Plastic Bag Use Reduction Act 2017 & & & & & & & & \\
\hline & Zero Disposable Plastic Policy, Executive Order No. 417 & & & & & & & & \\
\hline & $\begin{array}{l}\text { The National Solid Waste Management Strategy: } \\
\text { the roadmap towards a clean and safe Palau 2017-2026 }\end{array}$ & & & & & & & & \\
\hline \multirow{4}{*}{$\begin{array}{l}\text { Papua New } \\
\text { Guinea }\end{array}$} & Environmental Contaminants Act 1978 & & & & & & & & \\
\hline & Environment Act 2000 & & & & & & & & \\
\hline & Public Health Act 1973 & & & & & & & & \\
\hline & STaR & & & & & & & & \\
\hline
\end{tabular}


Table 5. Cont.

\begin{tabular}{|c|c|c|c|c|c|c|c|c|c|}
\hline Country & Legislation & $\begin{array}{c}\text { Trade in } \\
\text { Non-hazardous, } \\
\text { Recyclable and } \\
\text { Reusable } \\
\text { Plastics }\end{array}$ & $\begin{array}{l}\text { Legal Basis for } \\
\text { Sustainable } \\
\text { Financing } \\
\text { Mechanisms }\end{array}$ & $\begin{array}{l}\text { Infrastructure } \\
\text { Investments }\end{array}$ & $\begin{array}{c}\text { Economic } \\
\text { Development/ } \\
\text { Legal Basis for Loss } \\
\text { or Damage }\end{array}$ & $\begin{array}{l}\text { National } \\
\text { Reduction Targets }\end{array}$ & $\begin{array}{l}\text { Virgin Plastic } \\
\text { Use }\end{array}$ & $\begin{array}{c}\text { Market } \\
\text { Restrictions }\end{array}$ & $\begin{array}{c}\text { Promotion of } \\
\text { Traditional } \\
\text { Solutions }\end{array}$ \\
\hline \multirow{5}{*}{ Samoa } & Marine Pollution Prevention Act 2008 & & & & & & & & \\
\hline & $\begin{array}{l}\text { Samoa Water Authority Act 2003-Samoa Water } \\
\text { Authority (Sewerage and Wastewater) Regulations } 2009\end{array}$ & & & & & & & & \\
\hline & Waste Management Act 2010 & & & & & & & & \\
\hline & Waste (Plastic Bag) Management Regulations 2018 & & & & & & & & \\
\hline & National Waste Management Strategy 2019-2023 & & & & & & & & \\
\hline \multirow{4}{*}{$\begin{array}{l}\text { Solomon } \\
\text { Islands }\end{array}$} & National WMAP Strategy & & & & & & & & \\
\hline & $\begin{array}{l}\text { The Environmental Health (Public Health Act) } \\
\text { Regulations } 1980\end{array}$ & & & & & & & & \\
\hline & Environment Act 1998 & & & & & & & & \\
\hline & Shipping (Marine Pollution) Regulation & & & & & & & & \\
\hline \multirow{4}{*}{ Tonga } & Waste Management (Plastic Levy) Regulations 2013 & & & & & & & & \\
\hline & $\begin{array}{l}\text { Environment Protection Act (2008)—Litter and Waste } \\
\text { Control Regulations 2013 }\end{array}$ & & & & & & & & \\
\hline & Marine Pollution Prevention Act & & & & & & & & \\
\hline & Hazardous Wastes and Chemicals Act 2010 & & & & & & & & \\
\hline \multirow{7}{*}{ Tuvalu } & Waste Management Act 2017 & & & & & & & & \\
\hline & $\begin{array}{l}\text { Waste Management (Litter and Waste Control) } \\
\text { Regulations } 2018\end{array}$ & & & & & & & & \\
\hline & Waste Management (Levy Deposit) Regulation 2019 & & & & & & & & \\
\hline & $\begin{array}{l}\text { Waste Management (Prohibition on the Importation of } \\
\text { Single-Use Plastic) Regulation } 2019\end{array}$ & & & & & & & & \\
\hline & $\begin{array}{l}\text { Environment Protection Act (2008)—Litter and Waste } \\
\text { Control Regulations 2013 }\end{array}$ & & & & & & & & \\
\hline & Ozone Layer Protection Act (2008) & & & & & & & & \\
\hline & Integrated Waste Policy and Action Plan 2017-2026 & & & & & & & & \\
\hline \multirow{4}{*}{ Vanuatu } & $\begin{array}{l}\text { National Action Plan to Reduce Releases of } \\
\text { Unintentional Persistent Organic Pollutants 2018-2022 }\end{array}$ & & & & & & & & \\
\hline & Waste Management Act 2014 & & & & & & & & \\
\hline & Regulations 2018 & & & & & & & & \\
\hline & Ozone Layer Protection Act 2010 & & & & & & & & \\
\hline
\end{tabular}


Pacific LOSIDS can only respond to the risks associated with climate change-plastic pollution nexus if they are aware of these risks. Possible responses include policy change or voicing the limitations of their ability to respond without global support at international fora. However, few countries make the connection between plastics and climate change (three out of 52 documents; Table 5). Fiji's Climate Change Bill 2019 is one exception, but it is yet to be enacted. It stands to be one of the most comprehensive pieces of plastic pollution legislation across the study documents. The Bill recognises the impact marine plastic pollution has on the health of the marine environment and that a healthy climate relies on a healthy ocean. It also acknowledged that a healthy climate means a healthy human population. Part 14, Section 92 is dedicated to reducing plastic pollution. The Republic of Fiji National Climate Change Policy 2012 draws connections between climate change and waste but not plastics specifically. The Policy acknowledges that climatic conditions will impact landfill management practices and recommends reducing household burning, improved landfill management, and increased recycling facilities and collection.

While most countries do not connect plastic pollution to climate change, some appreciate the link between climate change resilience and waste management infrastructure more broadly. For example, the Papua New Guinea (PNG) National Climate Compatible Development Management Policy recommends a national infrastructure policy which would improve solid waste management in such a way that there would be increased resilience in the face of extreme weather events exacerbated by climate change. However, carbon-intensive and polluting waste-to-energy technologies are presented as a pathway to achieve resilience. A key objective of the Solomon Islands' National Waste Management and Pollution Control Strategy 2017-2026 is "waste management and pollution control are fully addressed in response to climate change impacts and natural disasters". However, the Strategy also claims that neither the Montreal Protocol nor the Ozone Layer Convention is relevant to waste management. This is likely to explain why the Solomon Islands has not enacted ozone layer legislation as some of the other Pacific LOSIDS in the study have. Some other study countries understand that CFC-blown plastic foams (e.g., rigid polyurethane foam used to insulate buildings, appliances, pipes and tanks) are banned under the Montreal Protocol because they release chlorine as the material breaks down, thus contributing to ozone depletion. Palau's Ozone Layer Protection Regulations, for example, domesticate the Montreal Protocol by prohibiting the import or use of any plastic foams containing ozone-depleting chemicals.

\subsubsection{Waste Hierarchy}

The Zero Waste Europe waste hierarchy illustrates a comprehensive and contemporary zero waste model (Figure 1) which goes beyond the 3Rs (reduce, reuse, and recycle) and 4 Rs (refuse, reduce, reuse, recycle) model to include rethinking, redesigning and preparing for reuse. Policy frameworks that focus on the top of the waste hierarchy endeavour to 'turn off the plastic pollution tap' at source (i.e., at extraction, pre-production design, production, manufacture and importation). Objectives and principles that focus high at the waste hierarchy (Figure 1) will "provide the mandate to further investigate the adoption of legislation that holds various stakeholders [e.g. producers, retailers, importers, service companies, packaging companies, distributors] accountable for their waste" [23] (p. 14). There are many other iterations of the zero-waste hierarchy that have been created by organisations all over the world. For example, Figure 2 presents the waste hierarchy as adapted by Maori zero waste organisation Para Kore ("zero waste") for Aotearoa New Zealand.

Some key documents reference 3 Rs, some refer to 4 Rs. However, $80 \%$ of the study documents do not reference any waste hierarchy. The legislative instruments in most of the study countries are aimed at down-stream processes, (i.e., post-consumption waste management) rather than preventative measures that would pre-empt the need for expensive and comparatively ineffective downstream technologies, infrastructure and other waste management responses. 


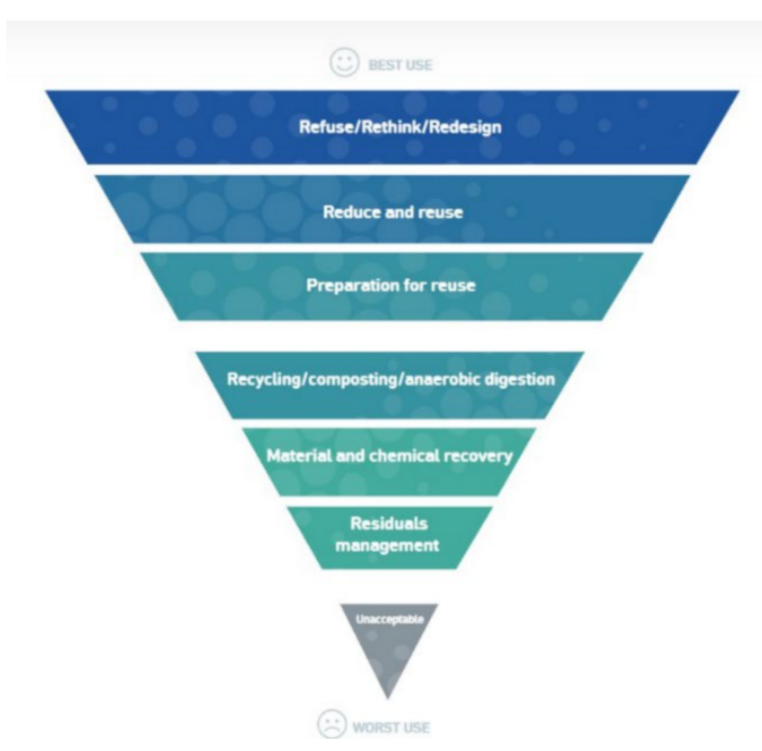

Figure 1. Zero Waste Hierarchy (Source: Simon 2019).

\section{The Waste Hierarchy}

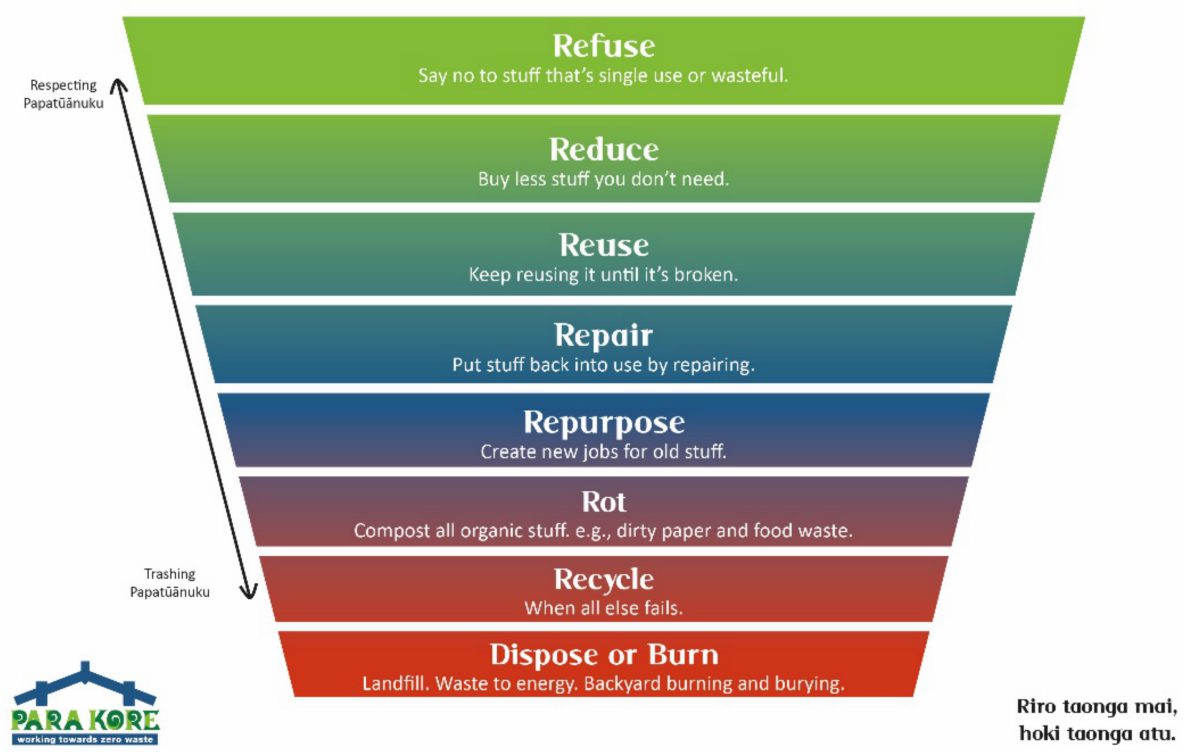

Figure 2. Para Kore Waste Hierarchy (Source: Para Kore 2020).

\subsection{Prevention}

Many Pacific LOSIDS rely heavily on imported goods, although a small number of businesses in the region manufacture a narrow range of plastic products. Therefore, there is a limited ability to influence the design of the products consumed in the region. Currently, only six of the 52 key documents include commitments to the prevention of the flow of problematic plastics into the country with a focus at the top of the waste hierarchy (Table 1). This means Pacific LOSIDS are investing limited resources and finances into waste management while investing relatively little in prevention and reduction responses. Preventative measures could include regulating the importation and domestic trade. These measures could include limiting the plastics circulating within the economy to those that are safe, recyclable and reusable, setting measurable national reductions targets and promoting traditional, plastic-free materials and systems (Table 5). Significant reductions in the quantity of virgin plastics produced and consumed are also key to the long-term elimination of plastics emissions into environments. Some study countries' ozone layer protection 
restrictions cover the importation of expanded polystyrene beads (Table 5). However, only Palau plans to control virgin pellets as outlined in the National Solid Waste Management Strategy: The Roadmap Towards a Clean and Safe Palau 2017-2026. No country in the study regulates the importation nor use of virgin pre-production pellets or flakes. In addition, there are no plans to monitor, manage nor set reduction targets for virgin plastics in the key documents.

In this study, 'Market Restrictions' refer to the regulation of plastics manufactured and consumed domestically. This includes the regulation of certain polymers (including bio/degradable plastics) and additives, and controls on the use of EDCs, POPs, and carcinogens. These regulations may also have been included in the 'Trade in Non-Hazardous, Recyclable and Reusable Plastics' theme. However, here the 'trade' theme refers to imports and exports of plastics and chemicals associated with plastics. The regulation of the trade of plastics could include bans, standards for plastics imports and exports, fees/levies/taxes on problematic imported plastics, and arrangements with producers outside the region that involve the repatriation of those products at the end of their useful life.

The most common market restriction option applied to plastics is to impose bans. This may be because they present less complex and resource-intensive implementation mechanisms than others. Tuvalu's Prohibition on the Importation of Single-Use Plastic Regulation 2019 prohibits the most comprehensive list of single-use items seen across the documents analysed. This includes the import, manufacture, sale and distribution of single-use plastics listed under Section 5 (1): shopping bags, plastic water bottles, plastic water pouches and plastic ice block bags, straws, plastic and polystyrene plates, cups, takeaway containers (including those with a plastic coating or lining), cutlery, food wrapping, tablecloths and flags.

Fiji employs financial mechanisms that incentivise the reduction of problematic plastics and disincentivise non-environmentally friendly choices. The Fiji Customs Tariff Act (2009) levies tariffs on imported and exported single-use or non-recyclable plastics and their National Solid Waste Management Strategy 2011-2014 recommends duties on non-environmentally friendly products, coupled with inducements for environmentally friendly products. This is also partly reflected in the PricewaterhouseCoopers Fiji National Budget 2019-2020 which states that fiscal duty on biodegradable kitchenware and tableware would be reduced from $32 \%$ to $0 \%$; and for non-woven plastic bags, on-fiscal duty will be increased from 15\% to 32\%. Under the Customs Tariff Act (p. 11) (and under Fiji's Environment and Climate Adaptation Levy [ECAL]), the plastic levy would be increased from 20 cents to 50 cents on Low-Density Polyethylene (LDPE) plastic bags effective from 1 January 2020. It should be noted here that a growing number of jurisdictions are restricting the production and consumption of bio/degradable plastic alternatives because they present similar harms to humans and the environment as traditional petroleum-based plastics (including NZ and the EU).

In only a few other cases do national documents clearly state where a levy would be invested. For example, Tuvalu's Prohibition on the Importation of Single-Use Plastic Regulation 2019 makes provisions for a levy on certain imported products to "support the recovery, processing, treatment and shipment of incoming goods at the end of their operation conditions; provide a mechanism for revenue collection and administration; and provide a legal framework that encourages waste avoidance and resource recovery behaviour".

Not all the study countries' bans were import bans. Vanuatu's Waste Management Act 2014, for instance, prohibits the manufacture, sale, or provision of disposable containers, single-use plastic bags, and plastic straws. However, like Fiji's Climate Change Bill 2019, this does not extend to the prohibition of the importation of these items. Yet, some governments are leading by example by banning disposable plastics in their procurement arrangements. In 2018, Palau's President, Remengesau Jr, issued Executive Order No. 417 under the powers of the Constitution establishing the Zero Disposable Plastic 
Policy. The Executive Order states, "All government offices and agencies shall immediately stop the practice of providing disposable plastics and polystyrene beverage containers".

Traditional plastic-free materials can offer locally-sourced, economic, and convenient alternatives to problematic plastics (e.g., single-use, unnecessary, non-recyclable plastics) (See Table 1). However, these local/traditional plastics alternatives may be most effectively captured in the policy. When adapting national policy frameworks to meet international or regional obligations, local culture, values and bylaws are crucial in the effective implementation of national policy. For example, in Tuvalu, the buy-in of village councils and chiefs is necessary to legislate waste under local governance laws: the Falekaupule Act (as amended 2008) regulates the composition, operation and functions of local governance (see also the Fijian Affairs Act 1978 and iTaukei Affairs Act 1944). However, overall, there is little integration of traditional culture and local governance nor traditional solutions across the study documents (Table 5).

\subsection{Management}

While the focus of this study is waste prevention, if well-designed, waste management options (Table 6) can be used to reduce the flow of problematic plastics into the environment. One of the key challenges in waste management in Pacific LOSIDS is funding, with the cost of waste management generally falling to the public sector. All the study countries' strategies and plans indicate that waste prevention, reuse, repair, redesign, and management lack sustainable financing mechanisms.

Extended producer responsibility (EPR) is based on the principle of 'polluter pays' whereby plastic producers and manufacturers are required to design, manage, and finance programs for end-of-life management of their products and packaging as a condition of sale. EPR is often used interchangeably with 'product stewardship'. However, product stewardship is a broader approach that ensures all parties involved in the supply chain of the product take responsibility for the impacts of that product. One of the most promising financially sustainable product stewardship schemes appearing across Pacific LOSIDS are container deposit or return schemes (CDS/CRS). Palau presents a CDS success story because the CDS for recyclable plastics is now financially sustainable. This is due to the dedicated recycling fund established under the Recycling Act 2006. The CDS has a 90\% recovery rate and since 2013, when the CDS became operational, it has processed $\sim 3$ tonnes of waste per month (Beverage Container Recycling Program Annual Report FY 2011-2016). Other potential benefits from expanding the CDS include income generation from the informal recovery sector, reductions in the damage costs for the local fisheries operations, and amenity value for coastal communities and tourism [35]. The success of the CDS and recycling scheme in Koror, Palau is the result of initial financial investment and expertise provided by the government of Japan. It should also be noted that Koror is the wealthiest and most populated state and has an established infrastructure and well-connected roads facilitating access for collection [36].

The Kiribati CDS has been promoted as another 'best practice' recycling system in the Pacific (Kiribati 20-year Vision 2016-2036). However, efforts to sustain the CDS scheme for polyethylene terephthalate (PET) bottles have been unsuccessful due to a lack of capacity, capability, and confusion among the public. This is the result of multiple agencies operating the waste management systems (37). As of 2018, the CDS has effectively halted and tonnes of plastics imported annually remain in the country. A review by the New Zealand Ministry of Foreign Affairs and Trade found that the main barrier to participation in the kaoki mange! ('return the rubbish!') scheme on Kiritimati is access, as there is only one drop-off location servicing several remote settlements [37].

The transport of waste and recyclables is a challenge across the region due to the geographical spread of the countries across the Pacific Ocean, the broad distribution of islands within each country, remote rural communities, and poor transport infrastructure to those areas. One of the strategic actions of Tuvalu's Integrated Waste Policy and Action Plan 2017-2026 is to reduce spatial limitations by developing public-private partnerships 
in the delivery of waste services. This could improve markets for waste streams, provide business opportunities and ensure sustainable financing including a system of backloading of recycled waste (including plastics) to potential markets. This strategic action is a result of a study conducted by Japan International Cooperation Agency (JICA) [38], which recommended strong public sector involvement in the recycling business.

Table 6. Waste Management gap analysis of key documents using the analytical framework. Green indicates explicit mention of the theme in the document, yellow indicates that the document either partially includes the theme or that it is inferred and red indicates that that theme is absent in the document.

\begin{tabular}{|c|c|c|c|c|}
\hline Country & Legislation, Policies and Plans & $\begin{array}{c}\text { Closed-Loop } \\
\text { Recycling (Primary } \\
\text { Market) or } \\
\text { Secondary Markets }\end{array}$ & $\begin{array}{l}\text { Remediation and } \\
\text { Legacy } \\
\text { Pollution }\end{array}$ & Transport \\
\hline \multirow{6}{*}{ Fiji } & $\begin{array}{c}\text { Environment Management Act 2005/Amendments and } \\
\text { Regulations } 24 \text { June } 2019\end{array}$ & & & \\
\hline & Litter Act 2008 and Litter (Amendment) Act (2010) & & & \\
\hline & $\begin{array}{l}\text { Public Health Act } 1935 \text { including Public Health } \\
\text { Regulations } 1937 \text { (as at } 1 \text { August 2018) [PHA 128]; and Public } \\
\text { Health and Sanitary Services Regulations } 1941\end{array}$ & & & \\
\hline & Climate Change Bill 2019 & & & \\
\hline & Republic of Fiji Climate Change Policy 2012 & & & \\
\hline & Fiji National Solid Waste Management Strategy 2011-2014 & & & \\
\hline \multirow{5}{*}{ Kiribati } & Environment (Amendment) Act 2007 & & & \\
\hline & Special Fund (Waste Materials Recovery) Act 2004 & & & \\
\hline & Kiribati Solid Waste Management Plan (KSWMP) & & & \\
\hline & Kiribati 20-year Vision 2016-2036 or KV20 & & & \\
\hline & Kiribati Development Plan 2016-2019 & & & \\
\hline \multirow{4}{*}{$\begin{array}{l}\text { Marshall } \\
\text { Islands }\end{array}$} & $\begin{array}{l}\text { Styrofoam cups and plates, and plastic products prohibition, } \\
\text { and container deposit Act } 2016\end{array}$ & & & \\
\hline & $\begin{array}{l}\text { Styrofoam Cups and Plates, and Plastic Products Prohibition } \\
\text { Container Deposit (Amendment) Act, } 2018 \text { (2018-0054) }\end{array}$ & & & \\
\hline & National Environment Management Strategy 2017-2022 & & & \\
\hline & $\begin{array}{l}\text { Kwajalein Atoll Local Government Solid Waste Management } \\
\text { Plan 2019-2028 }\end{array}$ & & & \\
\hline \multirow{5}{*}{ Palau } & National Code: Title 24: Environmental Protection & & & \\
\hline & The Recycling Act 2006 (including 2009 Amendments) & & & \\
\hline & Plastic Bag Use Reduction Act 2017 & & & \\
\hline & Zero Disposable Plastic Policy, Executive Order No. 417 & & & \\
\hline & $\begin{array}{l}\text { The National Solid Waste Management Strategy: the roadmap } \\
\text { towards a clean and safe Palau 2017-2026 }\end{array}$ & & & \\
\hline \multirow{4}{*}{$\begin{array}{l}\text { Papua New } \\
\text { Guinea }\end{array}$} & Environmental Contaminants Act 1978 & & & \\
\hline & Environment Act 2000 & & & \\
\hline & Public Health Act 1973 & & & \\
\hline & STaR & & & \\
\hline \multirow{5}{*}{ Samoa } & Marine Pollution Prevention Act 2008 & & & \\
\hline & $\begin{array}{l}\text { Samoa Water Authority Act 2003—Samoa Water Authority } \\
\text { (Sewerage and Wastewater) Regulations } 2009\end{array}$ & & & \\
\hline & Waste Management Act 2010 & & & \\
\hline & Waste (Plastic Bag) Management Regulations 2018 & & & \\
\hline & National Waste Management Strategy 2019-2023 & & & \\
\hline
\end{tabular}


Table 6. Cont.

\begin{tabular}{|c|c|c|c|c|}
\hline Country & Legislation, Policies and Plans & $\begin{array}{c}\text { Closed-Loop } \\
\text { Recycling (Primary } \\
\text { Market) or } \\
\text { Secondary Markets }\end{array}$ & $\begin{array}{c}\text { Remediation and } \\
\text { Legacy } \\
\text { Pollution }\end{array}$ & Transport \\
\hline \multirow{4}{*}{$\begin{array}{l}\text { Solomon } \\
\text { Islands }\end{array}$} & National WMAP Strategy & & & \\
\hline & The Environmental Health (Public Health Act) Regulations 1980 & & & \\
\hline & Environment Act 1998 & & & \\
\hline & Shipping (Marine Pollution) Regulation & & & \\
\hline \multirow{4}{*}{ Tonga } & Waste Management (Plastic Levy) Regulations 2013 & & & \\
\hline & $\begin{array}{c}\text { Environment Protection Act (2008)__Litter and Waste Control } \\
\text { Regulations } 2013\end{array}$ & & & \\
\hline & Marine Pollution Prevention Act & & & \\
\hline & Hazardous Wastes and Chemicals Act 2010 & & & \\
\hline \multirow{8}{*}{ Tuvalu } & Ozone Layer Protection Act & & & \\
\hline & Waste Management Act 2017 & & & \\
\hline & Waste Management (Litter and Waste Control) Regulations 2018 & & & \\
\hline & Waste Management (Levy Deposit) Regulation 2019 & & & \\
\hline & $\begin{array}{l}\text { Waste Management (Prohibition on the Importation of Single-Use } \\
\text { Plastic) Regulation } 2019\end{array}$ & & & \\
\hline & $\begin{array}{c}\text { Environment Protection Act (2008)—_itter and Waste Control } \\
\text { Regulations } 2013\end{array}$ & & & \\
\hline & Ozone Layer Protection Act (2008) & & & \\
\hline & Integrated Waste Policy and Action Plan 2017-2026 & & & \\
\hline \multirow{4}{*}{ Vanuatu } & $\begin{array}{l}\text { National Action Plan to Reduce Releases of Unintentional } \\
\text { Persistent Organic Pollutants 2018-2022 }\end{array}$ & & & \\
\hline & Waste Management Act 2014 & & & \\
\hline & Regulations 2018 & & & \\
\hline & Ozone Layer Protection Act 2010 & & & \\
\hline
\end{tabular}

\subsection{Microplastics}

The theme afforded the least attention and, therefore, regulation across all Pacific LOSIDS examined here is 'Microplastics' (Table 7). This is likely due to a lack of information regarding the hazards they present. All plastics that enter marine, freshwater, and terrestrial ecosystems will eventually degrade into micro- and nano-sized plastic fragments. Primary microplastics are those intentionally added to products. For example, those found in controlled release fertilisers, some cosmetics, commercial and industrial paints (including road markings), detergents, and abrasives. Secondary microplastics are those that are created through degradation. These can be released into agricultural soil when plastics in mulch, greenhouses, and compost degrade. They can also be introduced into agricultural soils when sewage sludge from waste treatment plants is applied to land as fertiliser. Other examples of secondary microplastics are tyre dust caused by wear and tear [39] and microfibres from synthetic fabrics [40]. The only document that referenced microplastics was Palau, which plans to control virgin pellets ('preproduction pellets'/'nurdles') as outlined in the National Solid Waste Management Strategy: The Roadmap Towards a Clean and Safe Palau 2017-2026. However, no handling guidelines, standards, or specific control mechanisms are cited in the document.

\subsection{Standardisation}

UNEA's Resolution 2/11: Marine Plastic Litter and Microplastics emphasises the need for Parties to develop "a harmonised environmental monitoring framework" including "methodologies and formats for the purposes of establishing baselines and inventories in collaboration with the Joint Group of Experts on the Scientific Aspects of Marine Environ- 
mental Protection (GESAMP) and/or other dedicated bodies" [20] (p. 8). Standardisation can take many forms including a harmonized system of national monitoring and reporting of plastics and associated chemical imports, manufacturing, recycling, export, disposal, and emissions; the establishment and maintenance of national inventories, enforcement and a harmonized set of definitions applied across the region; and certification schemes (Table 8). Standardisation also includes freedom of information, for example, ecolabeling, that informs consumers about the impacts of products and packaging. None of the key documents includes requirements for the labelling of plastics.

Table 7. Microplastics gap analysis of key documents using the analytical framework. Green indicates explicit mention of the theme in the document, yellow indicates that the document either partially includes the theme or that it is inferred and red indicates that that theme is absent in the document.

\begin{tabular}{|c|c|c|c|c|c|}
\hline Country & Legislation & $\begin{array}{l}\text { Intentionally Added } \\
\text { (e.g., Microbeads) }\end{array}$ & $\begin{array}{l}\text { Wear and Tear (e.g., } \\
\text { Tyres, } \\
\text { Textiles) }\end{array}$ & Agriplastics & $\begin{array}{l}\text { Management (e.g., } \\
\text { Pellets) }\end{array}$ \\
\hline \multirow{6}{*}{ Fiji } & $\begin{array}{c}\text { Environment Management Act 2005/Amendments and } \\
\text { Regulations } 24 \text { June } 2019\end{array}$ & & & & \\
\hline & Litter Act 2008 and Litter (Amendment) Act (2010) & & & & \\
\hline & $\begin{array}{l}\text { Public Health Act } 1935 \text { including Public Health } \\
\text { Regulations } 1937 \text { (as at } 1 \text { August 2018) [PHA 128]; } \\
\text { and Public Health and Sanitary Services Regulations } 1941\end{array}$ & & & & \\
\hline & Climate Change Bill 2019 & & & & \\
\hline & Republic of Fiji Climate Change Policy 2012 & & & & \\
\hline & Fiji National Solid Waste Management Strategy 2011-2014 & & & & \\
\hline \multirow{5}{*}{ Kiribati } & Environment (Amendment) Act 2007 & & & & \\
\hline & Special Fund (Waste Materials Recovery) Act 2004 & & & & \\
\hline & Kiribati Solid Waste Management Plan (KSWMP) & & & & \\
\hline & Kiribati 20-year Vision 2016-2036 or KV20 & & & & \\
\hline & Kiribati Development Plan 2016-2019 & & & & \\
\hline \multirow{4}{*}{$\begin{array}{l}\text { Marshall } \\
\text { Islands }\end{array}$} & $\begin{array}{l}\text { Styrofoam cups and plates, and plastic products } \\
\text { prohibition, and container deposit Act } 2016\end{array}$ & & & & \\
\hline & $\begin{array}{c}\text { Styrofoam Cups and Plates, and Plastic Products } \\
\text { Prohibition Container Deposit (Amendment) } \\
\text { Act, } 2018 \text { (2018-0054) }\end{array}$ & & & & \\
\hline & National Environment Management Strategy 2017-2022 & & & & \\
\hline & $\begin{array}{l}\text { Kwajalein Atoll Local Government Solid Waste } \\
\text { Management Plan 2019-2028 }\end{array}$ & & & & \\
\hline \multirow{5}{*}{ Palau } & National Code: Title 24: Environmental Protection & & & & \\
\hline & The Recycling Act 2006 (including 2009 Amendments) & & & & \\
\hline & Plastic Bag Use Reduction Act 2017 & & & & \\
\hline & Zero Disposable Plastic Policy, Executive Order No. 417 & & & & \\
\hline & $\begin{array}{l}\text { The National Solid Waste Management Strategy: } \\
\text { the roadmap towards a clean and safe Palau 2017-2026 }\end{array}$ & & & & \\
\hline \multirow{4}{*}{$\begin{array}{l}\text { Papua } \\
\text { New } \\
\text { Guinea }\end{array}$} & Environmental Contaminants Act 1978 & & & & \\
\hline & Environment Act 2000 & & & & \\
\hline & Public Health Act 1973 & & & & \\
\hline & STaR & & & & \\
\hline \multirow{5}{*}{ Samoa } & Marine Pollution Prevention Act 2008 & & & & \\
\hline & $\begin{array}{l}\text { Samoa Water Authority Act 2003-Samoa Water Authority } \\
\text { (Sewerage and Wastewater) Regulations } 2009\end{array}$ & & & & \\
\hline & Waste Management Act 2010 & & & & \\
\hline & Waste (Plastic Bag) Management Regulations 2018 & & & & \\
\hline & National Waste Management Strategy 2019-2023 & & & & \\
\hline \multirow{4}{*}{$\begin{array}{l}\text { Solomon } \\
\text { Islands }\end{array}$} & National WMAP Strategy & & & & \\
\hline & $\begin{array}{l}\text { The Environmental Health (Public Health Act) } \\
\text { Regulations } 1980\end{array}$ & & & & \\
\hline & Environment Act 1998 & & & & \\
\hline & Shipping (Marine Pollution) Regulation & & & & \\
\hline
\end{tabular}


Table 7. Cont

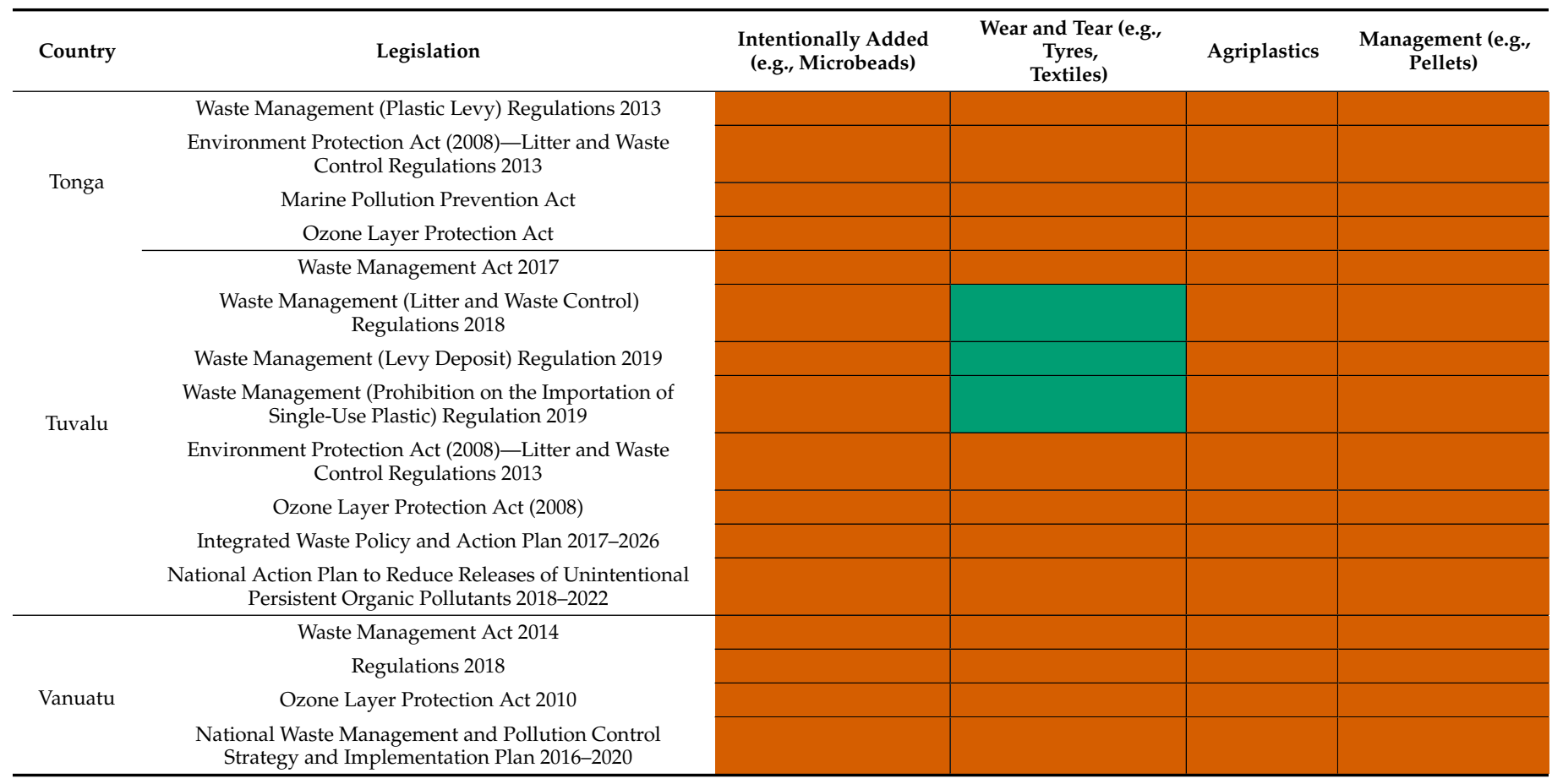

Standards ensure products, packaging and other delivery systems do not undermine zero waste circular economy efforts. Setting standards for products that are safe and fit for a circular economy will require a combination of labelling, product design, additive restrictions and certification schemes. A mandatory suite of product standardisation schemes will ensure all producers operate on a level playing field and that there are no free riders. All consumers can be confident that their products are toxic-free and are fit for a zero-waste circular economy. There is a lack of standardisation of the following definitions across documents: 'waste', 'plastic', 'refuse', 'garbage', 'litter', 'pollution', 'microplastic', 'marine debris', 'hazardous waste', 'emissions' and 'contaminant'. Only countries that provide definitions and use them consistently within policy documents are seen to be standardised. Indeed, many of the key words utilised in this analysis are applied interchangeably across documents. In addition, it is difficult to determine whether plastics are captured under these key terms even when definitions are provided. Other definitions that require standardisation include 'recovery' and 'polluter pays'. It is likely that the study countries will also need to standardise additional definitions in the future where freedom of information may be incorporated into plastic pollution policy (e.g., 'recyclable', 'compostable', 'EDC-free', 'POP-free', 'safe recycled content', 'microbead-free').

There are significant gaps in the monitoring and reporting and target-setting for plastic pollution across the study countries. Documents that include provisions for national monitoring and reporting seldom mention plastics. It is only assumed that plastics are incorporated into the monitoring and reporting of solid waste management. For example, Papua New Guinea's Environment (Amendment) Act 2014 includes environmental impact assessments, public review and submissions, environmental audits and investigations and environmental management plans for risk assessments including internal and external monitoring and reporting. However, none of these specifically target plastic pollution. Fiji's National Solid Waste Management Strategy 2011-2014 prioritises environmental monitoring (Chapter 10), but it does not include the volume and types of waste flowing into and through the economy nor waste leaking into the environment-including plastics. 


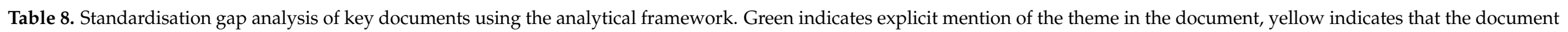
either partially includes the theme or that it is inferred and red indicates that that theme is absent in the document.

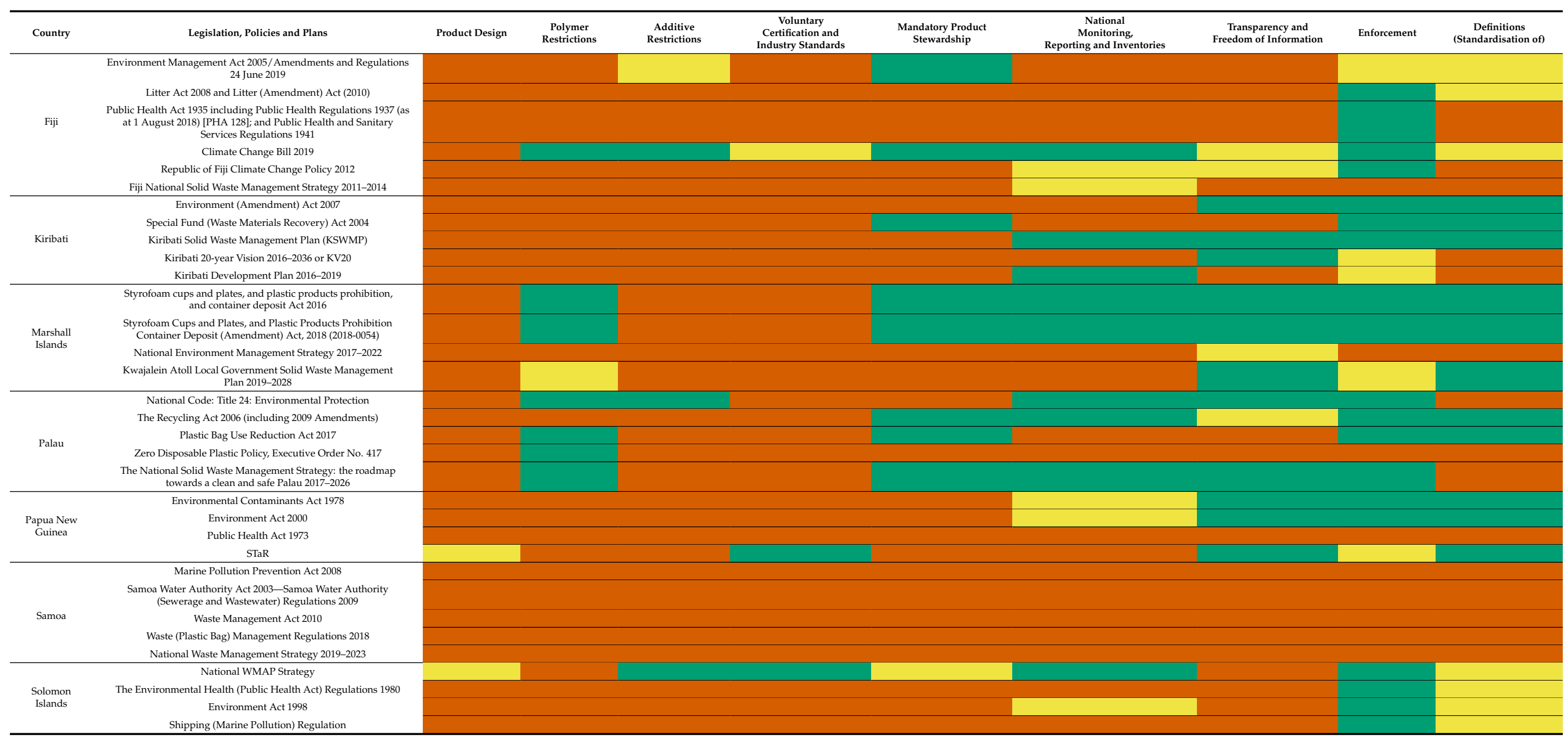


Table 8. Cont.

\begin{tabular}{|c|c|c|c|c|c|c|c|c|c|c|}
\hline Country & Legislation, Policies and Plans & Product Design & $\begin{array}{c}\text { Polymer } \\
\text { Restrictions }\end{array}$ & $\begin{array}{c}\text { Additive } \\
\text { Restrictions }\end{array}$ & $\begin{array}{c}\text { Voluntary } \\
\text { Certification and } \\
\text { Industry Standards }\end{array}$ & $\begin{array}{l}\text { Mandatory Product } \\
\text { Stewardship }\end{array}$ & $\begin{array}{c}\text { National } \\
\text { Monitoring, } \\
\text { Reporting and Inventories }\end{array}$ & $\begin{array}{l}\text { Transparency and } \\
\text { Freedom of Information }\end{array}$ & Enforcement & $\begin{array}{l}\text { Definitions } \\
\text { (Standardisation of }\end{array}$ \\
\hline \multirow{4}{*}{ Tonga } & Waste Management (Plastic Levy) Regulations 2013 & & & & & & & & & \\
\hline & $\begin{array}{c}\text { Environment Protection Act (2008)-Litter and Waste Control } \\
\text { Regulations 2013 }\end{array}$ & & & & & & & & & \\
\hline & Marine Pollution Prevention Act & & & & & & & & & \\
\hline & Hazardous Wastes and Chemicals Act 2010 & & & & & & & & & \\
\hline \multirow{7}{*}{ Tuvalu } & Ozone Layer Protection Act & & & & & & & & & \\
\hline & Waste Management Act 2017 & & & & & & & & & \\
\hline & $\begin{array}{l}\text { Waste Management (Litter and Waste Control) Regulations } 2018 \\
\text { Waste Management (Levy Deposit) Regulation } 2019\end{array}$ & & & & & & & & & \\
\hline & $\begin{array}{l}\text { Waste Managemente (Levy Deposit) Regulation } 2019 \\
\text { Waste Management (Prohibition on the Importation of Single-Use }\end{array}$ & & & & & & & & & \\
\hline & $\begin{array}{c}\text { Plastic) Regulation } 2019 \\
\text { Environment Protection Act (2008)-Litter and Waste Control }\end{array}$ & & & & & & & & & \\
\hline & $\begin{array}{c}\text { Regulations 2013 } \\
\text { Ozone Laver Protection Act (2008) }\end{array}$ & & & & & & & & & \\
\hline & Integrated Waste Policy and Action Plan 2017-2026 & & & & & & & & & \\
\hline \multirow{4}{*}{ Vanuatu } & $\begin{array}{l}\text { National Action Plan to Reduce Releases of Unintentional Persistent } \\
\text { Organic Pollutants } 2018-2022\end{array}$ & & & & & & & & & \\
\hline & Waste Management Act 2014 & & & & & & & & & \\
\hline & Regulations 2018 & & & & & & & & & \\
\hline & Ozone Layer Protection Act 2010 & & & & & & & & & \\
\hline
\end{tabular}


Most of the documents analysed included financial penalty, or in extreme cases, imprisonment for non-compliance. For example, Kiribati's Environment (Amendment) Act 2007, which targets plastic waste pollution broadly through multiple mechanisms, makes it an offence to litter with a maximum fine of $\$ 100,000$ or five years' imprisonment (s 12) and enforces a 'Duty to clean up the environment' to any person who causes or allows wastes to be discharged in contravention of the Act (s 20). However, national plans frequently note insufficient enforcement across solid waste management regulations and legislation across waste management (e.g., Samoa's National Plan p. 34). They also stress strengthening the legal frameworks and enforcement as a priority area.

\section{Key Recommendations}

Several Pacific LOSIDS are leading the world in plastic pollution prevention by implementing national plastic product bans and levies (e.g., Marshall Islands, Vanuatu, Niue, Samoa and Papua New Guinea). However, the core finding of this study is that national frameworks are weak and will require strengthening if they are to increase national levels of protection from non-transboundary flows of plastic pollution (i.e., to reduce national manufacture, consumption and improper disposal of problematic plastics). EIA's Pillar 2 on which the analytical framework of this study was based, also provides a measure of 'readiness' for countries to respond to a potential plastic pollution convention. An effective framework for developing internationally supported action to address plastic pollution could include suggestions offered here.

\subsection{Global Objectives}

Given that plastic pollution is a complex, cross-sectoral, and transboundary issue, successful governance approaches will need to involve the transposition of multilateral agreements into domestic legislation and policy, and function across national ministries and sectors (including health, customs, environment, maritime, community, women's and Indigenous affairs, conservation, agriculture, foreign affairs and trade, toxic substances control and primary industries). While all the study countries have ratified, signed, or acceded to regional and global instruments, protocols and conventions related to plastics pollution, the implementation of these obligations is poorly reflected in national legislation. Where the transposition of an international convention into national law is made, the focus is on waste management rather than preventative measures. Meeting obligations to enact national plans and legislation upon becoming a party to an international convention may be unattainable in many cases. This may be due to the absence of adequate, sustainable and long-term technical and scientific assistance and a lack of support for policy implementation, infrastructure, supportive technologies, partnerships, monitoring, reporting and enforcement measures.

To address these limitations and improve integration of international and regional obligations, countries may consider the establishment of a National Plastic Pollution Elimination Committee tasked with the development of a National Plastic Pollution Elimination Action Plan. National Pollution Elimination Plans could be the point at which international and regional agreements are transposed into national policy and legislation. National action plans would facilitate a more coordinated policy environment specific to each countries' needs. The Committee responsible for the development and regular revision of the plan may also be tasked with identifying challenges beyond national and regional capabilities, setting plastic pollution prevention targets, supporting public-private partnerships, highlighting where infrastructural investment is needed, supporting national or regional return and reuse scheme designs, and establishing monitoring, reporting and information exchange programmes and certification schemes. National committee representatives could convene regularly with SPREP and other regional partners to develop a Regional Plastic Pollution Elimination Action Plan to build on the strengths of the Pacific Regional Action Plan: Marine Litter 2018-2025 [17]. 
UNEP's EA.2/Res. 11 Marine Plastic Litter and Microplastics encourages the "establishment of harmonized international definitions and terminology" for plastics [41]. Plastic pollution is often subsumed and significantly diluted within the broad category of 'waste management', and a range of terms associated with plastics lack standardised definitions and best practice. Current policy in the study countries does not protect the health of Pacific Islands peoples nor the environment from the chemical and physical harms specific to plastic pollution. In addition, microplastics, pathogens and invasive species associated with plastics, nor the toxins associated with plastics (other than those emitted from open burning) are identified as public health issues in the study countries' policy and legislative frameworks. Faithful transposition of international agreements related to plastics including the Stockholm Convention could strengthen protections in Pacific Islands nations from these harms. An excellent example of this is the Solomon Islands National Implementation Plan for the Stockholm Convention on Persistent Organic Pollutants 2018. The Plan makes explicit links to human health across a range of plastics and lists some of the chemicals used in the production of plastics regulated under the Convention. The Plan also acknowledges the relationship between the consumption and disposal of plastics and the associated environmental and human health impacts at these points along the supply chain. The transposition of the Convention on Biological Diversity into domestic law could be strengthened to protect the health of Pacific Islands peoples. Human health is a focus in the interpretations of harmful substances and non-indigenous harmful aquatic organisms or pathogens in Samoa's Marine Pollution Prevention Act 2008. While provisions are made in the Act to protect against these harms, plastics are not mentioned in the Act despite contributing to these same harms.

All study countries have ratified The United Nations Framework Convention on Climate Change (1992) (UNFCCC) obligating them to transition towards renewable energy sources. For these commitments to be met, the connection between climate change and plastic pollution must be made explicit across national policy frameworks. The Paris Agreement of the UNFCCC specifically links plastic pollution to climate change impacts and requires that the plastic lifecycle must be managed to achieve net carbon neutrality by 2050. Making these connections explicit will strengthen the case for Pacific LOSIDS at international conventions to argue for the world's major producers of GHGs to shift to renewable energy and away from fossil fuel extraction and single-use plastics production. The investigation of waste-to-energy options appears to be an increasingly common theme across the Pacific region. However, a growing number of countries are discovering that these technologies do not support their climate change obligations. For example, a report commissioned by the Asian Development Bank (ADB) [42] found that the waste-to-energy facility considered for the Marshall Islands would not be financially viable. In addition, the facility would conflict with the Marshall Islands National Energy Policy and Energy Action Plan 2016 which aims for 20 percent renewable energy by 2020 and its efforts to minimise the human health impacts of climate change. A move to renewable energy means the rejection of waste-to-energy incineration. This shift may also include national recognition that $99 \%$ plastics are fossil-based [43] and that they emit methane as they degrade [5].

\subsection{Waste Prevention}

While the study countries do not produce virgin plastics, some import them to manufacture plastic products. Restricting virgin plastic imports and rewarding producers for a higher volume of recyclable content per unit produced will contribute to overall reduction in new plastics captured within the economy. Standards for manufacturers in the Pacific Islands can include caps on virgin resins, protocols for managing preproduction pellets, the use of safe monomer and additives, minimum recycled content, recyclability, reuse materials systems, repairability, and modularity.

While some Pacific LOSIDS are working toward circular economies, safe circular economies will remain elusive if hazardous additives, monomer and associated persistent organic pollutants (POPs) are not eliminated. Cleaner Pacific 2025 [44] illustrates that 
preventing plastic pollution will not be possible in the absence of a comprehensive policy framework that fosters sustainable consumption and production. The findings of this study corroborate these insights by underscoring the importance of sustainable financing mechanisms, transparency of information, monitoring and performance indicators and regional and national cooperation. Pacific LOSIDS may wish to consider two complementary options to restrict or prevent problematic plastics from entering their economies: prohibit or otherwise regulate the importation of problematic plastic products, including packaging, polymers and associated chemicals; as well as the application of taxes on these imported (the term 'imported' is intended to be applied broadly here to include incoming plastics from tourism, the fishing industry, the postal service, and shipping) products.

Countries may consider setting variable taxes on imported plastics. The more problematic the product, and the more restricted it is under international and regional conventions (e.g., the Basel Convention/Waigani Convention), the higher the tax. Such approaches could encourage the importation of safe and reusable, recyclable and/or repairable products. Levies could go to an environmental fund to support the recovery of legacy plastics and to develop infrastructure for reuse and recycling systems including collection, sorting and sanitizing. Expanding on pre-existing public-private partnerships across the Pacific region may also support the prevention, reduction and repatriation or removal of plastic pollution and could particularly support the repatriation or removal of plastic pollution from the region at end of useful life.

Generally, single-use bioplastics should be considered a prohibited category of imported products. There are several problems associated with the bioplastics available on the market today and the waste infrastructure required to manage them at end of life. The bioplastics that are currently available degrade at a similar rate to fossil fuel-based plastics when released into the environment and thus pose the same hazards to marine fauna [45]. Almost all of them contain endocrine-disrupting chemicals (EDCs) also known as 'hormone-mimickers' [46]. They release methane as they break down in anaerobic conditions (in landfills), and most bioplastics can only be composted in a commercial facility and the vast majority cannot be recycled [45,47]. Oxo-degradables are particularly problematic as they are fossil fuel-based and simply break down more readily in the environment. Consequently, a growing number of countries are banning them [45].

Increasingly, researchers, governments and civil society groups are calling for regional or national plastic pollution reduction targets [48-51]. National plans and policies can target the most problematic plastics. Priority plastics including single-use polyvinyl chloride (PVC) and polystyrene (PS and EPS) could be prohibited under a legislative instrument. This could trigger government-mandated EPR schemes for those priority products. These would need to be flexible enough to accommodate additional priority products as the need arose. There may be a case for an eco-levy on all single-use plastics to financially support and encourage a shift away from single-use to reusables and safe product design. A range of mandatory measures with inbuilt financial mechanisms could aid in setting and meeting ambitious and measurable national plastic pollution elimination targets. National plastic pollution elimination targets would ideally be linked to National Plastic Pollution Elimination Action Plans and would address all sources and quantifiable fates of plastics.

Traditional and local knowledge, values and alternatives to plastics (e.g., wood and banana leaves) are underutilized as solutions across the key documents. In 2018, prior to a national plastic bag ban in Aotearoa New Zealand, Māori weavers urged New Zealanders to use traditional kete (bags woven from flax) instead of plastic shopping bags [52]. Customary conservation practices such as $i$ qoliqoli in Fiji and $\mathrm{ra}^{\prime} u i$ in the Cook Islands, traditional leadership (e.g., Koutu Nui in the Cook Islands) and traditional women's groups could also play significant roles in influencing plastic pollution policy at multiple scales of governance, including at the village level. 


\subsection{Waste Management}

Pacific LOSIDS have become dependent on many plastic imports or on imported goods that come with plastic packaging. Legally binding provisions are required to ensure plastics that are imported into the region are safe and recyclable and/or reusable. Where plastics are necessary or unavoidable, 'repatriation' may be considered an additional ' $R$ ' to the '3Rs' (reduce, reuse, recycle) seen in many of the documents analysed in this study. EPR and producer responsibility can be used to motivate the producer or manufacturer to redesign products fit for a safe circular economy. Support for green accredited procurements could also support a zero-waste economy.

CDSs as examples of product stewardship are growing in popularity in the Pacific Islands where bans may not be appropriate for certain plastic products. A successful national CDS would champion backloading/reverse logistics and reuse systems. Backloading or reverse logistics involves loading empty shipping containers and trucks with post-consumer items once their cargo has been unloaded. The backloaded items can be either returned to point of origin or delivered to a site where they can be responsibly recycled, reused, repaired, or repurposed. Raubenheimer (2019) [23] recommends backloading as an affordable transport of freight option: "such a system could benefit transport operators in Pacific LOSIDS and provide a mechanism to transport clean, sorted waste from remote areas via delivery trucks and ferries" (p. iii). PRIF [35] has identified many Pacific LOSIDSports as currently having the annual cargo handling capacity for backloading and yet, they are not taking advantage of this due to a lack of resources required to collect, sort and transport recyclables to port. The Moana Taka Partnership, facilitated by SPREP and UNEP, is a mechanism intended to remove recyclable waste including plastic bottles out of some Pacific LOSIDS. Due to the relatively small markets in Pacific LOSIDS, product stewardship schemes such as CDSs coordinated at a regional level have the potential to support economies of scale and bargaining power. Mandatory product stewardship schemes such as CDSs level the playing field and ensure no-one free rides from operating outside the scheme. Successful CDSs are not only financially sustainable; they can also grow environment funds. These funds can then be used to expand the CDS to include a wider range of products, fund environmental clean-ups, remediation/recovery initiatives, develop sorting and sanitation processes and eventually expand the scheme to include (or swap out) all single-use items for refillables/reusables. Sustainable financing requires regular monitoring and reporting of all components of the system to demonstrate their ongoing effectiveness.

\subsection{Standardisation}

Streamlined monitoring, reporting and inventories specific to plastics would ensure data gathered on plastics could be used in multiple reports, reducing the burden of reporting on countries. An example of this may be to utilise the 10-digit globally harmonised system (GHS) for customs tariff codes. The globally collaborative development of, and compliance to, these standards is essential in ensuring plastics imports are safe and can be safely managed at end of useful life. Standardised labelling and other information standards and certification schemes will also ensure only safe recyclable or reusable materials are imported and manufactured. For example, Environmental Choice NZ operates to the ISO 14024 standard 'Environmental labels and declarations-Guiding principles.' This is based on the life cycle approach "to identify and understand environmental issues (adverse or beneficial impacts) across the whole life of a product or service (within a defined product or service category)." Labels can identify whether a product and its packaging or a service is a sustainable choice. Labelling can include additives or monomers of concern, recycled content, appropriate disposal methods, home or commercial compost-ability, hazard potential, intentionally added microplastics and recyclability. There are several examples of preexisting legislation where ecolabeling requirements could be included in the Pacific Islands. This includes PNG's Environmental Contaminants Act 1978 which is responsible for "prescribing the labelling, packaging, transportation, storage, advertising or use of 
any hazardous environmental contaminant"; Palau's Environmental Protection (Litter and Waste Control) Regulations 2013; Palau's Labelling Act 2015, and Kiribati's Environment (Amendment) Act 2007.

Compliance remains an ongoing challenge. While the legislation analysed is almost always supported by compliance measures (usually financial penalty or imprisonment), the level of enforcement is not clear. Financial support, a review of governance structures, monitoring and reporting, strengthening of capacity and increased public awareness may be required to support compliance and enforcement measures.

\subsection{Microplastics}

The word 'microplastics' was only identified in one of the key national documents analysed and few linkages were made between human health, climate change, and plastic pollution and pollutants. This may, in part, be the result of limited access to the latest science-based evidence on microplastics and plastic pollution more broadly. It is also likely to be because microplastics are less visible examples of plastic pollution.

\section{Conclusions}

The latest model on global plastics leakage shows that, at status quo, $36-90 \mathrm{Mt}^{-1}$ of plastics will leak into the environment over the next decade [4]. Individual national and regional efforts will barely put a dent in this figure; this will require immediate and extraordinary coordinated global efforts. There is growing support for a multilateral agreement to address plastic pollution. At the time of writing, approximately 130 countries had expressed interest in, or outright support for a global agreement including The Nordic Ministerial Declaration; Caribbean Community and Common Market St Johns Declaration; Endorsement presented in The Pacific Islands regional Marine Litter Action Plan; Durban Declaration; European Union Circular Economy Action Plan; Pacific Islands countries at the Asia Pacific Regional Ad Hoc Expert Group Meeting (AHEG); Africa Regional AHEG Meeting; Commonwealth Heads of Government. While there are opportunities to strengthen domestic responses to plastic pollution, addressing the transboundary nature of plastic pollution will require global support and coordination. While Pacific LOSIDS can strengthen legislation to restrict plastic imports or to disincentive their consumption domestically, they have no leverage over plastic production in other countries. Since Pacific LOSIDS do not produce plastics and have come to rely heavily on imported plastic and plastic-packaged goods, no domestic legislation will have any effect on global production volumes and product design. Only an agreement that regulates producers of plastic products will ensure caps on global virgin plastic production, and global standards for the design of safe, recyclable and reusable plastics. A global agreement could also provide scientific, financial and technical assistance to develop tailored national plastic pollution prevention action plans and policy tools. Pacific LOSIDS have consistently demonstrated leadership in international fora on marine health and climate change. Addressing plastic pollution also requires an urgent global response that reflects the needs of the countries and regions most directly affected.

Author Contributions: Methodology, T.A.F., S.F. and S.B.B.; validation, T.A.F., S.F. and S.B.B.; formal analysis, T.A.F., S.F. and S.B.B.; investigation, T.A.F., S.F. and S.B.B.; resources T.A.F., S.F. and S.B.B.; supervision, T.A.F.; data curation, T.A.F., S.F. and S.B.B.; writing-original draft preparation, T.A.F.; writing-review and editing, T.A.F., S.F. and S.B.B.; project administration, T.A.F.; funding acquisition, T.A.F.; visualisation, T.A.F., S.B.B. and S.F. All authors have read and agreed to the published version of the manuscript.

Funding: This research was funded by the Environmental Investigation Agency (EIA), United Kingdom, and the Massey University Research Fund, New Zealand.

Institutional Review Board Statement: Not applicable.

Informed Consent Statement: Not applicable. 
Data Availability Statement: Data used in this study are included in the Appendices A and B.

Acknowledgments: The authors are grateful for the support of participating countries, and the helpful comments from peer-reviewers.

Conflicts of Interest: This study was funded by the Environmental Investigation Agency (EIA): the organization that co-designed the Pillar of Action for a Convention on Plastic Pollution (2020) on which the thematic framework for this study is based. Two of the authors are members of an advocacy group including EIA legal staff which aims to support Pacific Island countries in international for on matters related to plastic pollution (e.g., the Ad Hoc Open-Ended Expert Group Meetings, Marine Litter and Microplastics and as part of the United Nations Environment Assembly process). The researchers adapted EIA's Prevention Pillar using supplementary themes that emerged from the literature review. EIA had no role in the following: the design of the study; the collection, analyses, or interpretation of data; the writing of the manuscript; or in the decision to publish the results.

\section{Appendix A}

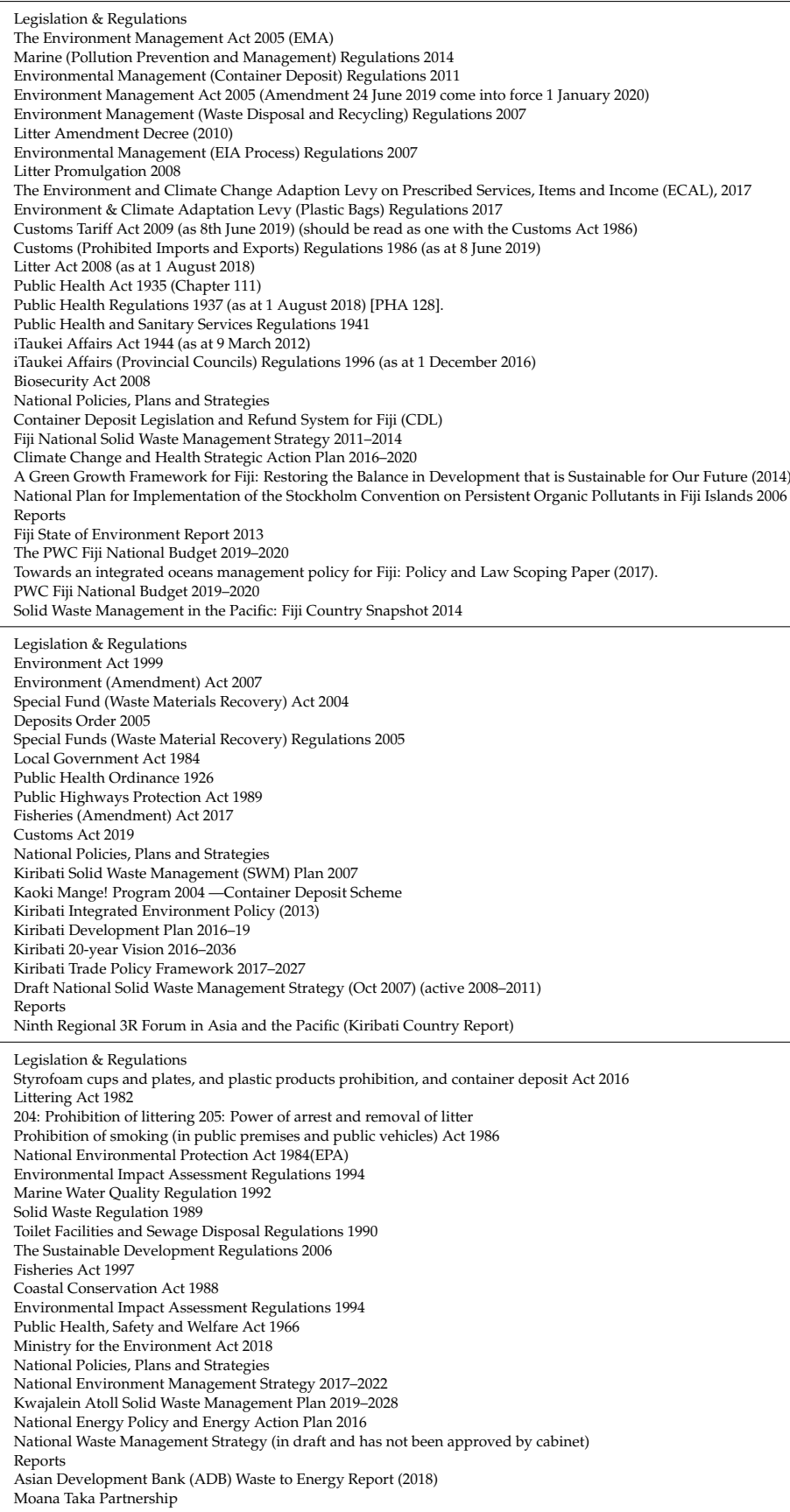




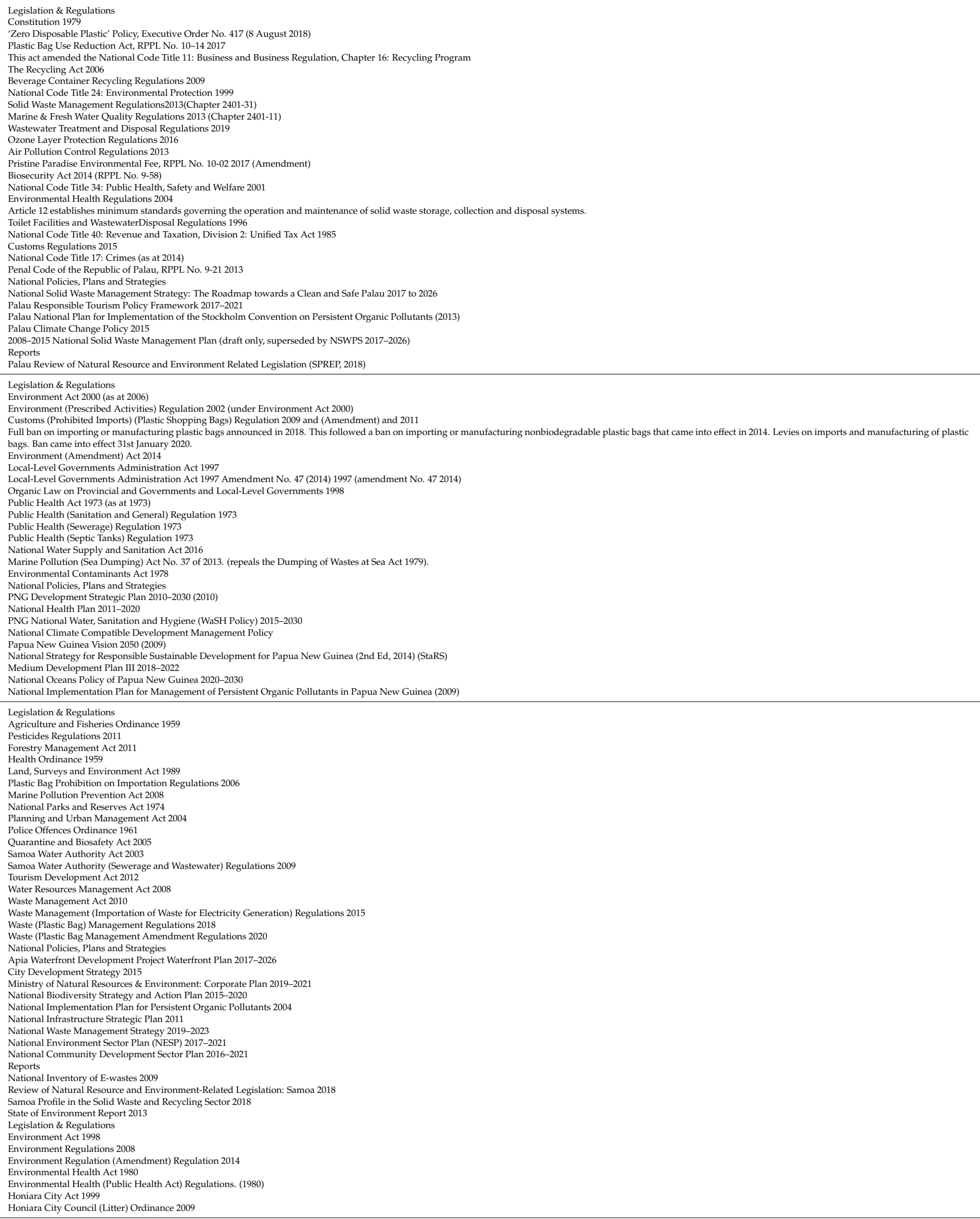




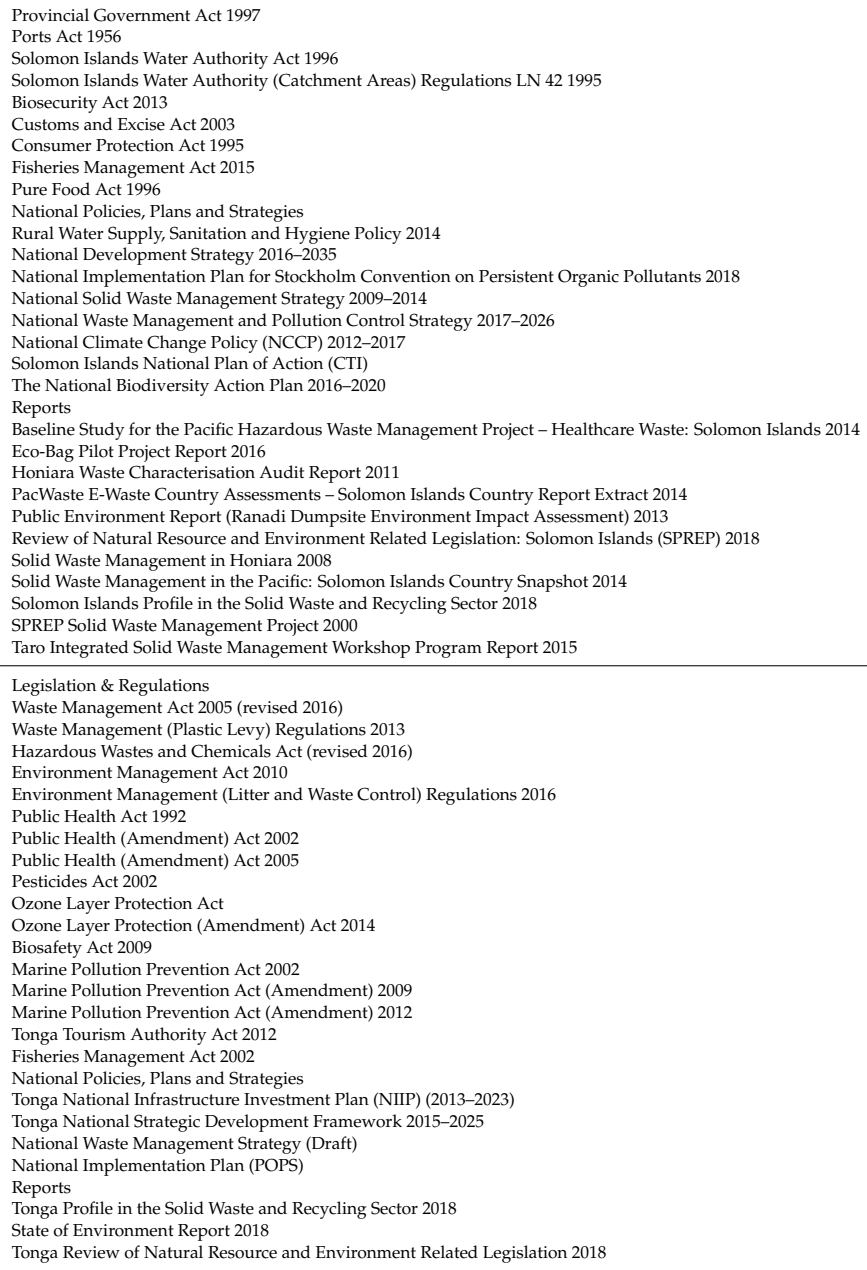


Water Resources Management Act 2002 (as at 2006)

Water Resorces Menct 2006 (as at

Public Health Act 1994

Public Health Act 1994
Public Health (Amendment) Act 2018

Ozone Layer Protection Act 2010

Ozone Layer Protection Act No. 27 of 2010

Ozone Layer Protection (Amendment) Act No. 4 of 2014

Schedule to the Ozone Layer Protection Act No. 27 of 2010 (Amendment) Order

National Policies, Plans and Strategies

National Waste Management and Pollution Control Strategy and Implementation Plan 2016-2020

Vanuatu National Water Strategy 2018-2030

National Sustainable Development Plan 2016-2030

National Biodiversity Strategy and Action Plan 2018-2030

\section{Appendix B}

The following sources and documents were cross-referenced:

- Duke University Plastics Policy Inventory

- FAOLEX

- ECOLEX

- $\quad$ The Pacific Islands Legal Information Institute (PacLII)

- Pacific Region Infrastructure Facility (2018) Pacific Region Solid Waste Management and Recycling Country and Territory Profiles. Pacific Region Infrastructure Facility (PRIF). Sydney, Australia.

- $\quad$ Peel, J., L. Godden, A. Palmer, R. Gardner, and R. Markey-Towler (2020). Stocktake of Existing and Pipeline Legislation in the 15 PacWastePlus Participating Countries. University of Melbourne, Melbourne, Australia

- $\quad$ Raubenheimer, Karen (2019). Desktop studies on principles of waste management and funding mechanisms in relation to the Commonwealth Litter Programme (CLiP): Vanuatu and Solomon Islands. University of Wollongong Australia, Wollongong, Australia.

- National official online sources of legislation. For example, the Laws of Fiji.

Additional documents and reference sources were accessed to ensure that all the international and regional agreements relevant to plastic pollution in each country were captured in the study:

- InforMEA

- Karasik, R., T. Vegh, Z. Diana, J. Bering, J. Caldas, A. Pickle, D. Rittschof, and J. Virdin. 2020. 20 Years of Government Responses to the Global Plastic Pollution Problem: The Plastics Policy Inventory. NI X 20-05. Durham, NC: Duke University.

- Environmental Investigation Agency (EIA). (April 2020). Islands of Opportunity: Toward a Global Agreement on Plastic Pollution for Pacific Island Countries and Territories. London, UK: EIA.

- Environmental Investigation Agency (EIA) (June 2020). Convention on Plastic Pollution: Toward a new global agreement to address plastic pollution. London, UK: EIA.

- $\quad$ SPREP (2019). PACPOL Strategy and Workplan prepared by Asia-Pacific ASA (APASA) for the Secretariat of the Pacific Regional Environment. Apia, Samoa: SPREP.

- $\quad$ SPREP (2016). Cleaner Pacific 2025: Pacific Regional Waste and Pollution Management Strategy 2016-2025. Apia, Samoa: SPREP.

- Commonwealth Marine Economies Programme (2018). Pacific Marine Climate Change Report Card.

\section{References}

1. Piccardo, M.; Provenza, F.; Grazioli, E.; Cavallo, A.; Terlizzi, A.; Renzi, M. PET microplastics toxicity on marine key species is influenced by $\mathrm{pH}$, particle size and food variations. Sci. Total Environ. 2020, 715, 136947. [CrossRef]

2. Pirsaheb, M.; Hossini, H.; Makhdoumi, P. Review of microplastic occurrence and toxicological effects in marine environment: Experimental evidence of inflammation. Process Saf. Environ. Prot. 2020, 142, 1-14. [CrossRef]

3. Steer, M.; Thompson, R.C. Plastics and Microplastics: Impacts in the Marine Environment. In Mare Plasticum-The Plastic Sea; Streit-Bianchi, M., Cimadevila, M., Trettnak, W., Eds.; Springer: Cham, Switzerland, 2020; pp. 49-72.

4. Borrelle, S.B.; Ringma, J.; Law, K.L.; Monnahan, C.C.; Lebreton, L.; McGivern, A.; Murphy, E.; Jambeck, J.R.; Leonard, G.; Hilleary, M.A.; et al. Predicted growth in plastic waste exceeds efforts to mitigate plastic pollution. Science 2020, 369, 1515-1518. [CrossRef] [PubMed] 
5. $\quad$ Royer, S.; Ferrón, S.; Wilson, S.T.; Karl, D.M. Production of methane and ethylene from plastic in the environment. PLoS ONE 2018, 13, e0200574. [CrossRef] [PubMed]

6. Shen, M.; Huang, W.; Chen, M.; Song, B.; Zeng, G.; Zhang, Y. (Micro) plastic crisis: Un-ignorable contribution to global greenhouse gas emissions and climate change. J. Clean. Prod. 2020, 254, 120138. [CrossRef]

7. Shen, M.; Ye, S.; Zeng, G.; Zhang, Y.; Xing, L.; Tang, W.; Wen, X.; Liu, S. Can microplastics pose a threat to ocean carbon sequestration? Mar. Pollut. Bull. 2020, 150, 110712. [CrossRef] [PubMed]

8. United Nations "The Future We Want": Outcome Document of the United Nations Conference on Sustainable Development, Rio de Janeiro; United Nations: Geneva, Switzerland, 2012.

9. Organisation for Economic Co-operation and Development. Making Development Co-Operation Work for Small Island Developing States; OECD Publishing: Paris, France, 2018.

10. United Nations Development Programme Oceans and Small Island States: First Think Opportunity, Then Think Blue. Available online: https:/ / www.undp.org/content/undp/en/home/blog/2017/2/22/Oceans-and-small-island-states-First-thinkopportunity-then-think-blue.html (accessed on 20 October 2020).

11. Andrew, N.L.; Bright, P.; de la Rua, L.; Teoh, S.J.; Vickers, M. Coastal proximity of populations in 22 Pacific Island Countries and Territories. PLoS ONE 2019, 14, e0223249. [CrossRef] [PubMed]

12. Richardson, K.; Haynes, D.; Talouli, A.; Donoghue, M. Marine pollution originating from purse seine and longline fishing vessel operations in the Western and Central Pacific Ocean, 2003-2015. Ambio 2017, 46, 190-200. [CrossRef]

13. Bartlett, R.V. Evaluating Environmental Policy Success and Failure. In Environmental Policy in the 1990s: Towards a New Agenda, 2nd ed.; Vig, N., Kraft, M., Eds.; Congressional Quarterly Press: Washington, DC, USA, 1994; pp. 167-197.

14. Ryan, P.G.; Schofield, A. Low densities of macroplastic debris in the Pitcairn Islands Marine Reserve. Mar. Pollut. Bull. 2020, 157, 111373. [CrossRef]

15. Lachmann, F.; Almroth, B.C.; Baumann, H.; Broström, G.; Corvellec, H.; Gipperth, L.; Hasselov, M.; Karlsson, T.; Nilsson, P. Marine plastic litter on small island developing states (SIDS): Impacts and measures. Swed. Instit. Mar. Environ. 2017, 4, 1-76.

16. United Nations Plastic Free-Pollution Free Fiji Campaign. Available online: https:/ / oceanconference.un.org/commitments/ ?id=21080 (accessed on 20 October 2020).

17. Secretariat of the Pacific Regional Environment Programme. Pacific Regional Action Plan: Marine Litter 2018-2025; SPREP: Apia, Samoa, 2018.

18. Raubenheimer, K.; Oral, N.; McIlgorm, A. Combating Marine Plastic Litter and Microplastics: An Assessment of the Effectiveness of Relevant International, Regional and Sub regional Governance Strategies and Approaches; United Nations Environment: Nairobi, Kenya, 2017.

19. Borrelle, S.; Rochman, C.; Liboiron, M.; Bond, A.; Lusher, A.; Bradshaw, H.; Provencher, J. Opinion: Why we need an international agreement on marine plastic pollution. Proc. Natl. Acad. Sci. USA 2017, 114, 9994-9997. [CrossRef] [PubMed]

20. Environmental Investigation Agency. Convention on Plastic Pollution: Toward a New Global Agreement to Address Plastic Pollution; EIA: London, UK, June 2020.

21. Farrelly, T.; Failler, P. Governing plastic pollution in the oceans: Institutional challenges and areas for action. Environ. Sci. Policy 2020, 112, 453-460.

22. Marra, M.; Di Biccari, C.; Lazoi, M.; Corallo, A. A gap analysis methodology for product lifecycle management assessment. IEEE Trans. Eng. Manag. 2017, 65, 155-167. [CrossRef]

23. Raubenheimer, K. Desktop Studies on Principles of Waste Management and Funding Mechanisms in Relation to the Commonwealth Litter Programme (CLiP): Vanuatu and Solomon Islands; University of Wollongong: Wollongong, NSW, Australia, 2019.

24. Cole, M.J. Benchmarking: A process for learning or simply raising the bar? Eval. J. Australas. 2009, 92, 7-15. [CrossRef]

25. Hsu, A.; Weinfurter, A.J.; Xu, K. Aligning subnational climate actions for the new post-Paris climate regime. Clim. Chang. 2017, 142, 419-432. [CrossRef]

26. Keohane, R.O.; Victor, D.G. The regime complex for climate change. Perspect. Politics 2011, 9, 7-23. [CrossRef]

27. Young, O. Institutional Dimensions of Environmental Change: Fit, Interplay, and Scale; MIT Press: Cambridge, MA, USA, 2002.

28. Abbott, K.W.; Genschel, P.; Snidal, D.; Zangl, B. International Organizations as Orchestrators; Cambridge University Press: Cambridge, UK, 2015.

29. Van Asselt, H.; Zelli, F. Connect the dots: Managing the fragmentation of global climate governance. Environ. Econ. Policy Stud. 2014, 16, 137-155. [CrossRef]

30. Campanale, C.; Massarelli, C.; Savino, I.; Locaputo, V.; Uricchio, V.F. Detailed review study on potential effects of microplastics and additives of concern on human health. Int. J. Environ. Res. Public Health 2020, 17, 1212. [CrossRef]

31. De-la-Torre, G.E. Microplastics: An emerging threat to food security and human health. J. Food Sci. Technol. 2020, 57, 1601-1608. [CrossRef]

32. Smith, M.; Love, D.C.; Rochman, C.M.; Neff, R.A. Microplastics in seafood and the implications for human health. Curr. Environ. Health Rep. 2018, 5, 375-386. [CrossRef]

33. Kassotis, C.D.; Vandenberg, L.N.; Demeneix, B.A.; Porta, M.; Slama, R.; Trasande, L. Endocrine-disrupting chemicals: Economic, regulatory, and policy implications. Lancet Diabetes Endocrinol. 2020, 8, 719-730. [CrossRef] 
34. Muncke, J.; Andersson, A.M.; Backhaus, T.; Boucher, J.M.; Almroth, B.C.; Castillo, A.C.; Chevrier, J.; Demeneix, B.A.; Emmanuel, J.A.; Fini, J.-B.; et al. Impacts of food contact chemicals on human health: A consensus statement. Environ. Health 2020, 19, 1-12. [CrossRef] [PubMed]

35. Pacific Region Infrastructure Facility. Pacific Region Solid Waste Management and Recycling-Pacific Country and Territory Profiles; PRIF: Sydney, Australia, 2018.

36. Starkey, L. Challenges to Plastic Up-Cycling in Small Island Communities: A Palauan Tale; Scripps Institute of Oceanography and Centre for Marine Biodiversity and Conservation: Sand Diego, CA, USA, 2017.

37. Niemi, M.; Carvan, A.; Williams, S. Mid-Term Evaluation of the Kiribati Solid Waste Management Programme; New Zealand Foreign Affairs and Trade Aid Programme: Wellington, New Zealand, 2019.

38. Japan International Cooperation Agency Data Collection Surveys on Reverse Logistics in the Pacific Islands; JICA: Tokyo, Japan, 2013.

39. Sommer, F.; Dietze, V.; Baum, A.; Sauer, J.; Gilge, S.; Maschowski, C.; Gieré, R. Tire abrasion as a major source of microplastics in the environment. Aerosol. Air Qual. Res. 2018, 18, 2014-2028. [CrossRef]

40. Napper, I.E.; Thompson, R.C. Release of synthetic microplastic plastic fibres from domestic washing machines: Effects of fabric type and washing conditions. Mar. Pollut. Bull. 2016, 112, 39-45. [CrossRef] [PubMed]

41. United Nations Environment Programme. UNEP/EA.2/Res. 11 Marine Plastic Litter and Microplastics; United Nations Environmental Programme: Nairobi, Kenya, 2016.

42. SCS Engineers Prefeasibility Study: Waste-to-Energy Facility, Majuro, the Republic of the Marshall Islands; Asian Development Bank: Marjuro, Marshall Islands, 2010.

43. Nielsen, T.D.; Hasselbalch, J.; Holmberg, K.; Stripple, J. Politics and the plastic crisis: A review throughout the plastic life cycle. Wiley Interdiscip. Rev. Energy Environ. 2020, 9, e360. [CrossRef]

44. Secretariat of the Pacific Regional Environment Programme. Cleaner Pacific 2025, Pacific Regional Waste and Pollution Management Strategy 2016-2025; SPREP: Apia, Samoa, 2016.

45. Northcott, G.; Pantos, O. Biodegradable and Environmental Impact of Oxo-Degradable and Polyhydroxylkanoate and Polylactic Acid Biodegradable Plastics; Parliamentary Commissioner for the Environment: Wellington, New Zealand, 2018.

46. Zimmermann, L.; Dierkes, G.; Ternes, T.A.; Völker, C.; Wagner, M. Benchmarking the in vitro toxicity and chemical composition of plastic consumer products. Environ. Sci. Technol. 2019, 53, 11467-11477. [CrossRef]

47. Parliamentary Commissioner for the Environment. Biodegradable and Compostable Plastics in the Environment; PCE: Wellington, New Zealand, 2018.

48. Simon, N.; Knoblauch, D.; Mederake, L.; McGlade, K.; Schulte, M.L.; Masali, S. No More Plastics in the Ocean. Gaps in Global Plastic Governance and Options for a Legally Binding Agreement to Eliminate Marine Plastic Pollution. Draft Report for WWF to Support Discussions at the Ad Hoc Open-Ended Expert Group on Marine Litter and Microplastics; Adelphi: Berlin, Germany, 2018.

49. New Zealand Office of the Prime Minister's Chief Science Advisor. Rethinking Plastics in Aotearoa New Zealand; NZPMCSA: Wellington, New Zealand, 2019.

50. Simon, J.M. A Zero Waste Hierarchy for Europe. New Tools for New Times: From Waste Management to Resource Management; Zero Waste Europe: Brussels, Belgium, 2019; Available online: https: / / zerowasteeurope.eu/2019/05/a-zero-waste-hierarchy-for-europe/ (accessed on 2 February 2020).

51. Zero Waste Europe. Seizing the Opportunity: Using Plastic Only Where It Makes Sense. Available online: https: / / rethinkplasticalliance.eu/wp-content/uploads/2018/08/ZWE-Position-paper-Plastics-reduction-targets.pdf (accessed on 20 October 2020).

52. Ling, J. Maori Weavers Call for Kete to Replace Plastic Bags. Stuff. 8 August 2018. Available online: https:/ / www.stuff.co.nz/ auckland/local-news/northland/106068446/maori-weavers-call-for-kete-to-replace-plastic-bags (accessed on 3 January 2020). 